\title{
How Can Music Be Torturous?: Music in Nazi Concentration and Extermination Camps
}

\author{
JULIANE BRAUER
}

Primo Levi, in what is one of the most prominent written accounts of life in the AuschwitzBirkenau extermination camp, recounted an incident he witnessed in the infirmary there:

The beating of the big drums and the cymbals reach us continuously and monotonously, but in this weft the musical phrases weave a pattern only intermittently, according to the caprices of the wind. The tunes are few, a dozen, and the same ones every day, morning and evening: marches and popular songs dear to every German. They lie engraven on our minds and will be the last thing in the Lager that we shall forget: they are the voice of the Lager, the perceptible expression of its geometrical madness, of the resolution of others to annihilate us first as men in order to kill us more slowly afterwards. ${ }^{1}$

Levi forcefully describes how music purposefully attacked prisoners' identities, certainties, selfconceptions, and sense of humanity. The fact that music played an important role in the Holocaust is neither a new discovery nor is it surprising. We know, based on survivors' memoirs, that music was part of daily life in National Socialist concentration and extermination camps. Survivors' accounts clearly convey how concentration camp prisoners could draw on music as a resource to aid in their survival, but music served equally as the most striking symbol of the inherent lunacy of the camp. Levi completes his description of the incident in the infirmary: "We all look at each other from our beds, because we all feel that this music is infernal." Levi uses the term "infernal" deliberately and links the music in the camps to Dante's Inferno. By emphasizing the danger inherent in music that was-in this context-demonic and nightmarish, Levi attributes to music a rather specific impact.

"Can music be considered as a form of torture?" was the question recently posed by musicologists in a special edition of the journal Torture. ${ }^{3}$ The guest editors were two of the academics responsible for the creation of the Free Floater Research Group, Music, Conflict and the State, situated at the University of Göttingen. Over the course of six years, group members contributed to an investigation of the relationship between music and violence in contexts marked by uneven power dynamics. ${ }^{4}$ Drawing on Article 5 of the 1948 Universal Declaration of Human Rights, they defined torture as "cruel, inhuman and degrading

I would like to thank Suzanne Cusick, Dagmar Ellerbrock, Luis-Manuel Garcia, Stephanie Olsen, Yael Sela-Teichler, Veronika Springmann for their crucial input and enthusiastic encouragement, as well the anonymous reviewers for their important comments. I'd also like to thank Christopher Geissler for his great help in translating and proofreading the text. ${ }^{1}$ Primo Levi, If This Is a Man/The Truce (Suffolk: Abacus, 1987), 56-7. The title of Guido Fackler's book makes reference to this passage; see Guido Fackler, “Des Lagers Stimme” - Musik im KZ: Alltags und Häftlingskultur in den Konzentrationslagern 1933 bis 1936 (Bremen: Ed. Temmen, 2000).

${ }^{2}$ Levi, If This Is a Man, 56.

${ }^{3}$ Anna Papaeti and Morag J. Grant, "Introduction," Torture: Fournal of Rehabilitation of Torture Victims and Prevention of Torture 23 (2013): 1.

${ }^{4}$ See Music, Conflict, and the State, at the University of Göttingen (https://www.uni-goettingen.de/en/207622.html), accessed 17 December 2014. This group was unfortunately disbanded in April 2014. 
treatment or punishment (CIDT)" and, citing a number of historical and contemporary examples, argued that music could constitute a form of CIDT and could therefore be defined as torture. ${ }^{5}$ Morag Grant pointed to a particular challenge posed by this debate. The vast majority of people consistently believe music to have positive attributes alone:

Such is often the case, for example, when it comes to reflections on how music was used in Nazi concentration camps: despite extensive evidence to the contrary, there is a tendency to latch on to the sense of hope and dignity and the promise of survival. [...] The only problem is that this reading of music's role in the camps conveniently pastes over the other aspects: its use to humiliate and psychologically and physically destroy people. ${ }^{6}$

The use of music as a type of violence was not unique to Nazi camps, nor was music an exceptional kind of torture in this context. Nevertheless, I argue that the use of music as torture was refined and enhanced in the "universe" of "absolute power" that was created in these camps. ${ }^{7}$ Music was combined in Nazi concentration and extermination camps with other forms of physical and emotional torture in ways previously unimagined and to a completely new extent. In this combination music had the potential to destroy prisoners' humanity in ways that would not be possible using physical forms of torture alone. A more nuanced understanding of music and emotion will demonstrate how music as torture was developed in the Nazi camps to devastating effect, allowing the camps' guards and commanders to assault the deepest core of what it means to be human, depleting prisoners' final resource for survival when they have already been starved, beaten, and overworked: their own sense of self. An examination of the forms of music as torture that were developed in Nazi camps is necessary in order to better situate historically recent debates about more current examples of the use of music in torture contexts. ${ }^{8}$ Drawing on these debates and the Göttingen research group's efforts to define certain uses of music as constituting incidents of cruel, inhuman, or degrading treatment, my analysis will reassess the presence, aims, and effects of music as a form of torture in the Nazi camps.

Any discussion of music as torture will necessarily focus on the interplay between music itself, human emotions, and the physical body. In this article, I seek to clarify, with reference to music in the Nazi camps, the ways in which music can have a potentially torturous effect on prisoners' minds and bodies and why music was chosen at these specific sites and in a variety of particular contexts in order to

\footnotetext{
${ }^{5}$ See, for example, "Music, Conflict and the State," in Music and Torture / Music and Punishment, ed. Morag J. Grant and Anna Papaeti, special issue of The World of Music (new series) 2 (2013): 1; Grant, "The Illogical Logic of Music Torture," Torture: Fournal of Rehabilitation of Torture Victims and Prevention of Torture 23 (2013): 4-13; and Grant, "Pathways to Music Torture," Transposition 4 (2014), http://transposition.revues.org/494.

${ }^{6}$ Grant, "The Illogical Logic," 5.

${ }^{7}$ The terms are taken from Wolfgang Sofsky, The Order of Terror: The Concentration Camp, 2nd ed. (Princeton: Princeton University Press, 1999), 17. They will be further contextualized below.

${ }^{8}$ A number of publications have appeared during the last five years dealing with the connection between music and torture. See, for example, Lily E. Hirsch, Music in American Crime Prevention and Punishment (Ann Arbor: University of Michigan Press, 2012), especially chap. 6, "Music as Torture.” For more on music's use in the Iraq War, see Jonathan Pieslak, Sound Targets: American Soldiers and Music in the Iraq War (Bloomington: Indiana University Press 2009). On violence as an essential part of popular music, see Bruce Johnson and Martin Cloonan, Dark Side of the Tune: Popular Music and Violence (Adlershot: Ashgate, 2008). And for more on music as tool of punishment in American antiterrorism camps such as Guantánamo, see especially the work of the American musicologist Suzanne G. Cusick, including "Music as Torture/Music as Weapon,” TRANS-Transcultural Music Review 10, no.11 (2006), http://www.sibetrans.com/trans/a152/music-as-torture-music-asweapon; "You are in a place out of the world': Music in the Detention Camps of the Global War in Terror," Fournal of the Society for American Music 2 (2008): 1- 26; "Musicology, Torture, Repair,” Radical Musicology 3 (2008). See also Suzanne G Cusick and Branden W. Joseph, "Across an Invisible Line: A Conversation about Music and Torture," Grey Room: Architecture, Art, Media, Politics 42 (2011): 6-22. In 2012, Tristan Chytroschek's documentary film Songs of War: Music as a Weapon, which also explored the relationship between music and torture, won the International Emmy Award for Best Arts Documentary.
} 
achieve this effect. To do this, I will draw on written and recorded memories, other documental sources, and the scholarly literature. I begin in the following section by outlining the history and the major shifts evident in both scholarly debates and the broader public discussions of the topic over the course of several decades. ${ }^{9}$

\section{State of the Research on Music in Nazi Concentration and Extermination Camps}

The topic of music in National Socialist camps can be divided into three sequential phases based on shared characteristics: early conservation and related initiatives (1945 to the 1970s); rediscovery and new discoveries (1980s and 90s); and firm anchoring in the scholarly discourse and public consciousness (2000 to present). There is a sizable body of Polish-language work on the camps dating from the 1960s onwards, including memoirs that specifically addressed cultural life in the camps. An examination of that literature is beyond the scope of this article, though a number of Polish-language works that have been translated into English or German will be referenced. Unfortunately only a limited number of the books and articles on camp experiences published in Polish have been translated thus far. ${ }^{10}$

Music in National Socialist camps was a "music-historical no man's land" in Germany until the 1980s, as the most important German music encyclopedia, Musik in Geschichte und Gegenwart, ${ }^{11}$ claimed. This critical characterization emphasizes the dearth of attention paid to the topic by scholars well into the 1980s, but it ignores the fact that there had been attempts to enlighten the broader public about the phenomenon of music in concentration camps. Survivors provided early reports about music in the camps, ${ }^{12}$ for example, and collections of songs from the ghettos began to appear shortly after the war's end. ${ }^{13}$ The work of Aleksander Kulisiewicz (1918-82), a survivor of Sachsenhausen, is a notable example. Immediately following his liberation from the camp, he dictated-from his sick bed-over seven hundred songs that had been performed in Sachsenhausen, each in its original language. He proceeded to dedicate his life to researching Polish songs that had been sung in the concentration camps, traveling throughout Eastern Europe to interview survivors, eventually publishing his findings in a medical-historical journal.

\footnotetext{
${ }^{9}$ This article does not consider music in the ghettos or music in Theresienstadt as a particular type of ghetto. For further information on music in the ghetto, see Eleanor Mlotek, We are here: Songs of the Holocaust (New York: Educational Dept. of the Workmen's Circle, 1983); Shoshana Kalisch and Barbara Meister, Yes We Sang! Songs of the Ghettos and Concentration Camps (New York: Harper \& Row, 1985); Gila Flam, Singing for Survival: Songs of the Lodz Ghetto (Urbana: University of Illinois Press, 1992); Joža Karas, Music in Terezín 1941-1945 (New York: Beaufort, 1985); and Shirli Gilbert, Music in the Holocaust: Confronting Life in the Nazi Ghettos and Camps (Oxford: Clarendon Press, 2005).

${ }^{10}$ One such translated text is Krzysztof Dunin-Wąsowicz, Resistance in the Nazi Concentration Camps 1933-1945, trans. Halina Dzierżanowska (Warszawa : PWN, 1982), originally published as Ruch oporu w hitlerowskich obozach koncentracyjnych, 19331945 (Warzawa 1979). More recent publications involving translation from the Polish include Wojciech Klimczyk and Agata Świerzowska, eds., Music and Genocide and an important contribution to the field from the Polish musicologist Katarzyna Naliwajek-Mazurek, "Music and Torture in Nazi Sites of Persecution and Genocide in Occupied Poland 1939-1945," in The World of Music (new series) 2 (2013): 31-50.

${ }^{11}$ Bernd Sponheuer, "Nationalsozialismus," in Musik in Geschichte und Gegenwart, ed. and comp. by Ludwig Finscher, Sachteil, vol. 7 (Kassel: Bärenreiter, 1997), 25-43.

${ }^{12}$ Szymon Laks, Music of Another World (Evanston: Northwestern University Press, 1989), which was first published in 1948 in French. There were also distinct references to the camp orchestra in early Polish films about the camps, including Ostatni Etap (The Last Stage), DVD, directed by Wanda Jakubowska (Poland, 1947; Chicago: Facets Video, 2009) and Pasazerka (Passenger), VHS, directed by Andrzej Munk (Poland, 1963; Bellingham: Hen's Tooth Video, 1997). These early engagements with the topic remained relatively unknown to a broader audience up until the 1990s.

${ }^{13}$ For example, Shmerke Kaczerginski, Lider fun di Getos un Lagern (New York: Tziko Bicher Farlag, 1948); Lazar Weiner, Songs of the Concentration Camps (New York: Itzchok-Hendele Foundation, 1948); Henech Kon, 30 Songs of the Ghetto (New York: Congress for Jewish Culture, 1960).
} 
From his life's work, he managed to produce a manuscript of 2,200 pages; it has yet to find a publisher. The Kulisiewicz archive, which comprises 52,000 meters of audio material and over 100,000 sheets of paper, is housed in the United States Holocaust Memorial Museum. ${ }^{14}$ Kulisiewicz's importance as an early conservator, researcher, and personal eyewitness to the Holocaust cannot be overstated. His collection remains one of the most significant archives of material related to the topic of music in the camps, making it of immeasurable value to researchers. ${ }^{15}$

Another early scholar of music in the camps was Inge Lammel, an East German researcher who worked on folk songs. She began in the 1960s to express a political and scholarly interest in the songs that had been sung by those imprisoned in the camps. Her work has provided us with the Workers' Songs Archive (Arbeiterliederarchiv, held at the Akademie der Künste, Berlin). This collection came together over the course of the 1960s and 70s as Lammel painstakingly assembled a history of songs from concentration camps that she characterized as "workers' and battle songs," 16 which had been sung for a variety of purposes by German communist prisoners. This archive is of continuing relevance and importance for researchers interested in the topic. ${ }^{17}$

By the late 1970s in both the United States and in Germany, the Holocaust had begun to assume a more central place in public awareness of the Nazi regime and the experience of World War II. Thanks largely to the film Playing for Time, which was shown on American television in 1980 to near universal praise from critics, and which garnered a number of nominations and awards, the broader public began to

\footnotetext{
${ }^{14}$ See Aleksander Kulisiewicz (http://holocaustmusic.ort.org/places/camps/centraleurope/sachsenhausen/kulisiewiczaleksander), and Juliane Brauer, "Aleksander Kulisiewicz," Lexikon verfolgter Musikerinnen und Musiker der NS-Zeit, 2010, http://www.lexm.uni-hamburg.de/object/lexm_lexmperson_00002619 (December 19, 2013). Kulisiewicz's primary publications include: Aleksander Kulisiewicz, Sachsenhausen Pamiętnik poetycki 1939-1945 (Lublin: 1965) [in German: Adresse Sachsenhausen. Literarische Momentaufnahmen aus dem KZ, ed. by Claudia Westermann (Gerlingen: Bleicher Verlag 1997)]; Aleksander Kulisiewicz, “Z zagadnień psychopatologii muzyki i pieśni w obozach hitlerowskich” (Psychopathology of Music and Songs in Nazi Camps), Przeglad Lekarski 31/1 (1974): 39-45; Aleksander Kulisiewicz, "Dalsze przyczynki do zagadnień psychopatologii muzyki i pieśni w obozach hitlerowskich" (Additional Contributions towards a Psychopathology of Music and Songs in Nazi Camps), Przeglad Lekarski, 32/1 (1975): 33-40; Aleksander Kulisiewicz, "Muzyka i pieśni jako współczynnik samoobrony psychicznej więzńiów w obozach hitlerowskich” (Music and Songs as a Factor in Prisoners' Psychological Self-Defense in Nazi Camps), Przegląd Lekarski, 34/1 (1977): 66-77; Aleksander Kulisiewicz, "Dalsze przyczynki do zagadnień muzyki i pieśni w zakresie samoobrony psychicznej więzńiów w obozach hitlerowskich" (Further Considerations on Music and Songs in Prisoners' Psychological Self-Defense in Nazi Camps), Przegląd Lekarski, 36/1 (1979): 38-50; Aleksander Kulisiewicz, Muzika i Pieśni w hitlerowskich obozach konzcentracyjnych 19331945 (Music and Songs in the Fascist Concentration Camps), Cracow, 1982 (unpublished manuscript, German translation housed in the archive of the Sachsenhausen Museum: P3).

${ }^{15}$ For example, M. Urbancyzk, Twórcyość i dziatność pieśniarska Aleksandra Kulisiewicza w obozie koncentracyjnym Sachsenhausen (1940-1945) [The Musical Works and Song Activities of Aleksander Kulisiewicz in Sachsenhausen (1940-1945)] (Uniwersytet Śląski 1981); Konrad Strzelewicz, Zapis: Opowieść Aleksandra Kulisiewicza. [Record: The Story of Aleksander Kulisiewicz] (Cracow: Krajowa Agencja Wydawnicza, 1984); David D. Hirsch, "Camp Music and Camp Songs: Szymon Laks and Aleksander Kulisiewicz," in Confronting the Holocaust: A Mandate for the 21st Century, Studies in the Shoah, eds. G. Jan Colijn and Marcia Sachs Littell (Oxford: University Press of America, 1997), 157-168; Bret Werb and Barabara Milewski, "From Madagascar to Sachsenhausen: Singing about 'Race' in a Nazi Camp," in Polin: Studies in Polish fewry, 16 (2003), 269-278; Juliane Brauer, Musik im Konzentrationslager Sachsenhausen (Berlin: Metropol, 2009); Barbara Milewski, "Remembering the Concentration Camps: Aleksander Kulisiewicz and his Concerts of Prisoner's Songs in the Federal Republic of Germany," in Dislocated Memories: Fews, Music, and Postwar German Culture, ed. Tina Frühauf and Lily E. Hirsch (Oxford; New York: Oxford University Press, 2014), 141-160. There are also audio recordings of Kulisiewicz's songs: see, Ballads and Broadsides: Aleksander Kulisiewicz's Songs from Sachsenhausen, United States Holocaust Memorial Museum, 2008. Songs from the Depths of Hell recorded in the early 1980's on LP by Folkways records.

${ }^{16}$ Inge Lammel and Günter Hofmeyer, Lieder aus den faschistischen Konzentrationslagern (Das Lied - im Kampf geboren, Heft 7) (Leipzig: Hofmeister, 1962). See also Inge Lammel, "Zur ethischen Funktion des deutschen KZ-Liedes," Musik und Gesellschaft 16 (1966): 148-153; Inge Lammel, Lied und Gesang im illegalen Widerstand gegen den Faschismus in Deutschland 19331945, Arbeiterklasse und Musik II, Berlin 1977 (Arbeitshefte der Akademie der Künste der DDR Nr. 22).

${ }^{17}$ See especially Gilbert, Music and Brauer, Sachsenhausen.
} 
display an increased interest in the role of music in the concentration camps. ${ }^{18}$ The now famous movie's screenplay, written by Arthur Miller, was based on an autobiographical novel by Fania Fenelon, a survivor of Auschwitz-Birkenau who had played in the women's orchestra there. The film was broadcast in two parts on German television in September 1981. The film's release seems to have helped spark a renewed effort during the 1980s and into the twenty-first century to record survivors' memories and publish survivors' memoirs. Among these were a number of musicians who had survived the camps. These publications responded to existing interest and helped stimulate even greater public interest in survivors' life stories more generally. ${ }^{19}$

Also in the 1980s, musicologists and anthropologists in West Germany began to collect information about music in concentration and extermination camps, though their efforts did not take into account the work that had been done already. ${ }^{20}$ Regardless, various groups of scholars were formed, putting music in National Socialist camps firmly on the broader research agenda, which also served to increase public awareness in West Germany of the ambivalent role music played in the camps. In his substantial review of this body of work, published in 1991, musicologist Eckhard John outlined the work that had already been done and identified areas that deserved more attention. ${ }^{21}$

Musicologists and historians working in a number of different languages began to address these lacunae during the 1990s and 2000s, interviewing survivors, combing through archives and publishing their findings. ${ }^{22}$ Scores of books and articles have examined music from a variety of different perspectives as it existed in a number of different camps. ${ }^{23}$ We now know that there was hardly a single National Socialist camp where music did not feature in some way, whether as a tool for survival or as a form of torture. Among works published in English, Shirli Gilbert's stands out for the ways in which it reconsiders the different forms of meaning music could assume in the camps and ghettos. Her book, Music in the Holocaust, was published in 2005 and remains the only English-language monograph on the topic. Taking the concept of the "gray zone" as her point of departure, Gilbert identified "myriad dimensions" to the music that had been played in Nazi camps and ghettos, asserting that these multiple meanings went far

\footnotetext{
${ }^{18}$ Fania Fenelon and Marcelle Routier, Playing for Time (New York: Atheneum, 1977), originally published as Sursis pour l'orchestre (Paris: Stock, 1976); German translation: Das Mädchenorchester in Auschwitz (Frankfurt am Main: Röderberg 1980). ${ }^{19}$ Hermann Sachnowitz, Auschwitz: Ein norwegischer Fude überlebte (Frankfurt am Main: Büchergilde Gutenberg, 1981); Dick Walda, Trompettist in Auschwitz: Herinneringen van Lex van Weren (Amsterdam: De Bataafsche Leeuw, 1989); Jacques Stroumsa, Violinist in Auschwitz: From Salonica to ferusalem, 1913-1967 (Konstanz: Hartung-Gorre, 1996); Coco Schumann, Der Ghetto-Swinger (Munich: Deutscher Taschenbuch Verlag, 1997); Anita Lasker-Wallfisch, Inherit the Truth, 1939-1945: The Documented Experiences of a Survivor of Auschwitz and Belsen (New York: St. Martin's Press, 2000); Ken Shuldman, Fazz Survivor: The Story of Louis Bannet, Horn Player of Auschwitz (London: Vallentine Mitchell, 2005).

${ }^{20}$ Joachim Martini, Musik in Auschwitz: Begleitheft zur gleichnamigen Ausstellung, Evangelische Initiative: Zeichen der Hoffnung, Znaki Nadziei (Frankfurt am Main, 1988); Zündende Lieder - Verbrannte Musik: Folgen des Nazifaschismus für Hamburger Musikerinnen und Musiker, ed. Peter Petersen (Hamburg: VsA 1995).

${ }^{21}$ Eckhard John, "Music and Concentration Camps: An Approximation," Fournal of Musicological Research 20, no. 4 (2001): 269-323 (first published in German as "Musik und Konzentrationslager: Eine Annäherung," Archiv für Musikwissenschaft 48 [1991]: 1-36).

${ }_{22}$ Milan Kuna, Hudba na hranici života: O činnosti a utrpení hudebníků z českých zemí vnacistických koncentračních táborech a věznicích, (Prague: Naše vojsko, 1990); Gabriele Knapp, Das Frauenorchester in Auschwitz: Musikalische Zwangsarbeit und ihre Bewältigung (Hamburg: von Bockel, 1996); Guido Fackler, "Des Lagers Stimme”: Musik im KZ: Alltags und Häftlingskultur in den Konzentrationslagern 1933 bis 1936 (Bremen: Ed. Temmen, 2000); Gabriele Knapp, Frauenstimmen: Musikerinnen erinnern an Ravensbrück (Berlin: Metropol, 2003); Gilbert, Music; Brauer, Sachsenhausen; Bruno Giner, Survivre et mourir en musique dans les camps nazis (Paris: Berg International, 2011).

${ }^{23}$ See the annotated bibliography in Fackler, Des Lagers Stimme, 501-68 and the comprehensive bibliography compiled by the team responsible for the Music and the Holocaust web portal: http://holocaustmusic.ort.org/resourcesreferences/bibliography/.
} 
beyond the "spiritual resistance" that had been the usual focus of previous analyses. ${ }^{24}$

Thanks to this and other work done over the past thirty years, which has built on early efforts to collect empirical data about the existence of music in concentration camps and gone far beyond that more circumscribed aim, we now have a much more substantive understanding of music in these places. We must acknowledge, however, that the restricted number of sources continues to limit this understanding. Items such as playbills, songbooks, single sheets with compositions, drawings by prisoners, and photos taken by SS guards are rare because the SS destroyed much of the documentation produced in the camps. This means that a good deal of information from the perspective of the SS camp administration is now completely lost. The dearth of documentation is not the only difficulty in reconstructing the musical world of the concentration camps. Decades separate the lived experiences of camp survivors and the recording of their memories, which were preserved in book form and on video, predominantly during the 1990s and 2000s. Their memories have been subject to variation over the course of this intervening time. Some things have been completely forgotten; sometimes in the retelling, certain aspects are highlighted while others are excluded. Because individual experiences varied, it may often seem that memories of music were or are of little importance to particular survivors. Memories related to music in the camps feature especially prominently in testimony provided by survivors for whom music played an important personal role during their time in the camps or, alternatively, when music is the specific focus of questions posed to survivors. ${ }^{25}$

We have seen significant strides over the course of the past twenty years in making information about music in the Nazi camps available to a broader public. Scholars, museums, and archives have dedicated themselves to the question of accessibility, with online collections featuring prominently in these efforts. ${ }^{26}$ These even include collections of the music of the Holocaust itself. ${ }^{27}$

The wealth of information now available in archival and public collections allows for a reconsideration of the role of music as an instrument of torture. This function of music has been discussed from one angle or another in the works that I have cited here. This article aims to provide a more comprehensive systematic analysis of the different forms - and thereby meanings—music understood as a type of torture in concentration and extermination camps. By taking a wider view of the variety of different manifestations of music as torture in the context of the camps, I seek to capture that dimension of music that Levi describes, in the passage I quote at the beginning of this article, as "infernal."

In her discussion of music and torture, Morag Grant asserts: "How people react to music in the context of torture is as individual as with any other type of torture; thus the use of music to torture should

\footnotetext{
${ }^{24}$ Gilbert, Music, 16-20.

${ }^{25}$ This observation is based on my own experiences with survivors from Germany, France, Poland, Netherlands and Norway. It is also evident in the interviews included in the "Visual History Archive of the Shoah Foundation" project, which records nearly fifty thousand interviews with Holocaust survivors: USC Shoah Foundation, The Institute for Visual History and Education. "Visual History Archive," http://sfi.usc.edu. Unless framed explicitly in the interviewer's questions or already a particularly significant part of the interviewee's life story, music in the camps is hardly mentioned.

${ }^{26}$ Examples include the website World ORT, “Music and the Holocaust," http://holocaustmusic.ort.org/ (December 18, 2014). This internet portal offers scholarly articles on individual camps and musicians, but also provides users with direct access to collected source material. The extensive bibliography and discography are particularly useful. Also see United States Holocaust Memorial Museum, "Music of the Holocaust: Highlights from the Collection: http://www.ushmm.org/exhibition/music/.

${ }^{27}$ A box set of 24 CDs was recently released with music from different National Socialist camps: Francesco Lotoro and Grazia Tiritiello, KZ Musik: Encyclopedia of Music Composed in Concentration Camps 1933-1945, 24 discs (Rome: Assoc. Culturale, 2008-2009). This is the largest and most comprehensive effort to provide the public with listening material from the camps themselves. There are a number of other CD projects, the details of which can be found at http://holocaustmusic.ort.org/resources-references/discography/.
} 
never be viewed as the lesser of many potential evils simply because not all survivors give it the same weight." 28 The power of music lies in its abilities to shape notions of identity, subjectivity, and belonging. For this reason, a focus on the body and emotions, both of which are targeted by torture, can go a considerable way toward offering an explanation of the potentially torturous nature of music. ${ }^{29}$ How can the perception and experience of music reconstruct-but also deconstruct-identities? In what ways does music affect the human body, and through which emotional responses? In answering these questions, we will be able to gain a more profound understanding of prisoners' everyday experience of life and death, of the microcosm of absolute power and uncertainty.

\section{Music, Emotion, Violence, and the Body}

Defining emotion is a project that is difficult enough, but mapping out the relationships between music and emotions is even more challenging and has been the subject of a number of studies over the past ten years. Though a close link between music and emotion has been demonstrated by neuroscientists and music psychologists, scholars working in the humanities describe this connection in a number of different ways. This is not entirely surprising, given the number of different principles and concepts on which their work draws. ${ }^{30}$ What is central to all of this work is the attempt to identify the ways in which the meaning of music and human feelings are interdependent. ${ }^{31}$ Depending on one's cultural socialization, music can be an important resource and medium for processing one's experiences and mediating one's perception through emotions. In the same way, music can be a means through which emotions themselves are produced, modulated, and acted out. We can therefore say that music supports what is called "emotion work." As the sociologist of music Tia DeNora has written, "Music is part of the reflexive constitution of that [internal emotional] state." 32

Given this interdependent nature, I would like to suggest that emotions are neither purely physical reactions to external stimuli on the part of the body, nor are they solely cultural constructs. ${ }^{33}$ Their meaning can be located beyond this discourse-defining dichotomy somewhere between the physical and the psychological, inside and outside, body and mind. They can be described as liminal phenomena. Emotions can be understood as marks or traces on bodies left by the contact between the inner self and the outer world. They quite literally leave their impression on a person by virtue of their acting as

\footnotetext{
${ }^{28}$ Grant, "Pathways," 3.

${ }^{29}$ Starting from the "social function of music," Grant identifies several different "pathways to music torture." These are :(1) the "sensory deprivation" pathway, (2) the military tradition pathway, (3) the political communication pathway, (4) the humiliation pathway, and (5) the power performance pathway. Grant, "Pathways." Though these pathways can be identified in the examples discussed below, I approach this issue from a cultural anthropological perspective focusing on the interplay of music, emotion, and the body.

${ }^{30}$ See Patrik N. Juslin and John A. Sloboda, Handbook of Music and Emotion: Theory, Research, Applications (Oxford: Oxford University Press, 2010). For the latest published work on the topic, see Tom Cochrane, Bernardino Fantini, and Klaus R. Scherer, The Emotional Power of Music: Multidisciplinary Perspectives on Musical Arousal, Expression, and Social Control (Oxford: Oxford University Press, 2013).

${ }^{31}$ This question was also brought up by the music therapist Joseph J. Moreno, though he failed to offer a satisfactory reply. "Orpheus in Hell: Music in the Holocaust," in Music and Manipulation: On the Social Uses and Social Control of Music, ed. Steven Brown and Ulrik Volgsten (New York, Oxford: Berghahn Books, 2006), 265.

${ }^{32}$ Tia DeNora, Music in Everyday Life (Cambridge: Cambridge University Press, 2000), 57.

${ }^{33}$ For more on work on the history of emotion by scholars in cultural studies and the differences between that field's approach and those taken by neuroscientists and psychologists as well as the different uses of the terms affect, feeling and emotion, see Jan Plamper, The History of Emotion: An Introduction (Oxford: Oxford University Press 2015).
} 
intermediaries between the self and society. ${ }^{34}$ Their power derives from the fact that they are a central dimension of a person's experience and perception of the world, a dimension that is embedded in individual and shared knowledge, manners, and attitudes. Through these contacts, new emotions are generated or already existing emotions are altered. Monique Scheer defines emotions as the practice of the "mindful body," a kind of "doing emotions": "The body is actor and instrument. It is not conceived of as an assembly of organic material and processes alone, but as a knowing body, one that stores information from past experiences and contributes it to human activity and consciousness." ${ }^{35}$ We need to acknowledge this connection between the physical body and the social body. ${ }^{36}$ Emotions stem from the body's knowledge, and as such, they can be conceived of as a learned bodily practice. Conversely, they also have the power to move and reshape the body.

By remaining attentive to the body, we will be better able to understand and explain how people perceive music and the role experiences, emotions, and performances play in perception. To start with, we might try to understand the process of perceiving music as a writing and rewriting of evanescent moments in or on the mindful body. For the purposes of the argument I make here, I suggest naming the space in which music and emotions come together a contact zone. ${ }^{37}$ This zone between the inner and outer worldbetween the self (the mindful body) and society-is strongly influenced by the actual conditions in which the music is perceived. The contact zone is where "emotion work" takes place. To illustrate this, I will use the example of a documented forced performance of "Ave Maria." In the middle of a bitterly cold winter night in 1942, two drunk SS guards at Sachsenhausen were beating prisoners outside their barracks. One of the SS guards, named Wilhelm Schubert, singled out one of the prisoners and held a gun to his chest: "He commanded him to sing the Ave Maria. Schubert was totally drunk; the prisoner couldn't sing because he was terrified. The other prisoners encouraged him and so he began to sing Ave Maria with a clear and pure sound. Tears run down his face." ${ }^{38}$ Music perception can inscribe the body with completely contrary emotions. One assumes that this particular prisoner would, after the scene described above, connect "Ave Maria" with feelings of fear, despair, or anger and, as a result, quite possibly overwrite, so to speak, previously held positive memories associated with the composition, ones connected to feelings such as happiness, joy, and tranquility. Prisoners' ability to affirm their identities through the medium of music, to draw strength from it, may be disturbed, if not completely destroyed, by the experience of violence. Whether that happened in this case is a matter of speculation, however, as we have no further records related to this particular prisoner. Similarly, we cannot know what effect the music in this situation had on the SS guards, whether it recalled anything from their own lives, for example. We do not even know if this episode ended with the prisoner's death. Nevertheless, this example illustrates how the contact zone of music perception may work as a site for modeling, restructuring, mediating, and imprinting emotions.

\footnotetext{
${ }^{34}$ See Sara Ahmed, "Collective Feelings: Or, the Impression Left by Others," Theory, Culture E Society 21, no. 2 (2004): $25-42$.

${ }^{35}$ Monique Scheer, "Are Emotions a Kind of Practice (and Is That What Makes Them Have a History)? A Bourdieuian Approach to Understanding Emotion," History and Theory 51, no. 2 (2012): 193-220 (200-1).

${ }^{36}$ See Nancy Scheper-Hughes and Margaret M. Lock, "The Mindful Body: A Prolegomenon to Future Work in Medical Anthropology," Medical Anthropology Quarterly 1, no. 1 (1987): 6-41.

${ }^{37}$ I use the term contact zone independently of Mary Louise Pratt, Imperial Eyes: Travel Writing and Transculturation (London and New York: Routledge, 1992). She developed the concept to describe "social spaces where disparate cultures meet, clash, and grapple with each other, often in highly asymmetrical relations of domination and subordination-like colonialism, slavery, or their aftermath as they are lived out across the globe today" (4). What our concepts of a contact zone share is the notion that the contact zone describes a (real or imagined) space in which interaction, communication, and mutual impact take place.

${ }^{38}$ Erwin Scheidel, Zeugenvernehmung im Ermittlungsverfahren gegen Sorge, Gustav und Schubert, Wilhelm (Oberscharführer) wegen Mordes, Interrogation record dated March 28, 1956, Archive Museum Sachsenhausen, Oranienburg Sig. JD 2/12, p. 91.
} 
Music itself has no inherent meaning or emotional content. This is what makes the contact zone necessary and productive. Music's effect and the emotions attached to music are strongly linked to experiences, those at the time of listening as well as past experiences that have already been internalized in the listener. The effect also depends on the circumstances surrounding perception, concrete practice, and performance. Furthermore, the impact of music is not entirely determined by the individual listener; it is dependent on broader, shared social factors and is subject to change over time. Both making music and listening to music are bodily emotional practices. The body learns to understand music and, during those formative experiences, links music with memory, meaning, and last but not least, emotions, all of which play a significant role in constituting a person's identity and sense of self-assurance. This is music's role in creating links between emotions and the outside world. It is an important medium for emotional work, for eliciting specific emotions, renewing or reshaping them, and is crucial in supporting self-assurance. This is why music could sometimes function as a tool for survival for certain prisoners, especially those for whom music had been a crucial aspect of their pre-camp lives and identities.

Listening to music and performing music are-under normal circumstances-voluntary activities. It is because of this normal state of affairs that we tend to treat music as something positive. ${ }^{39}$ But there is a growing awareness of "music's darker potential" in situations marked by an imbalance of power. ${ }^{40}$ The nonspecialist public has become more familiar with this aspect of music over the past few years with respect to the "war on terror." ${ }^{41}$ The use of music in National Socialist concentration and extermination camps belongs to a tradition of using music to accompany violence and torture, a practice that continues right up to the present day.

To explain how Nazi concentration and extermination camps provided a context in which this fusion of music and violence was possible, we must first turn to the concept of "absolute power": "It does not forgo violence, but liberates it from all inhibitions and impediments intensifying it by organization. [...] Absolute power is not bent on achieving blind obedience or discipline, but desires to generate the universe of total uncertainty." ${ }^{42}$ I borrow this term from the sociologist Wolfgang Sofsky, who developed it with specific reference to the Nazi camps. He argued that these were a special "laboratory of violence": "Virtually anything can be ventured, repeated, intensified, or halted, without reference to norms or goals. Absolute freedom is imbued in here with a barbaric ingenuity." 43 The use of music by SS guards in concentration camps in situations of absolute power, in which complete uncertainty existed as a general rule, allowed them to exert total control over prisoners' bodies. Forcing prisoners to listen to or perform music in these situations, such as the forced singing of "Ave Maria" referenced above, served to undermine expectations, experiences, and emotions that constituted the prisoners' identities. Given that listening to

\footnotetext{
${ }^{39}$ This is based on a romantic understanding of music. Lily E. Hirsch made the same observation about the Romantic ideals regarding music: "For many, music is thus incompatible with the negative idea of punishment." "Do you really want to hurt me?' Music as Punishment in the United States Legal System," Popular Music and Society 34, no. 1 (2011): 46. David Hesmondhalgh explicitly criticized "an overly optimistic understanding of music, which implicitly sees music as somehow independent of negative social and historical processes." "Towards a Critical Understanding of Music, Emotion and Selfidentity," Consumption Markets \& Culture 11, no. 4 (2008): 330.

${ }^{40}$ Hirsch, "Do you really want to hurt me?" 48.

${ }^{41}$ For more, see the Junior Free Floater Research Group: Music, Conflict, and the State at the University of Göttingen, https://www.uni-goettingen.de/en/207622.html. See also Johnson and Cloonan, Dark Side of the Tune, 31-48; Steve Goodman, Sonic Warfare: Sound, Affect, and the Ecology of Fear (Cambridge: MIT Press, 2010); and articles by Susan Cusick: "Music as Torture/Music as Weapon," TRANS-Transcultural Music Review, 10, no.11 (2006); "You are in a place out of the world: Music in Detention Camps of the Global War in Terror," Fournal of the Society for American Music, 2 (2008): 1-27; "Musicology, Torture, Repair," Radical Musicology, 3 (2008).

${ }^{42}$ Sofsky, Order of Terror, 17.

${ }^{43}$ Ibid., 23.
} 
and performing music are bodily emotional practices, intricately connected to memory and meanings formed through experiences, and that the mindful body is a potential contact zone for creating and (re)coding emotions, the prisoners' bodies and identities were profoundly vulnerable in the camps. Combining music with complete control over the prisoners' bodies allowed for the potential rewriting of those aspects of a prisoner's identity that had been derived from music and musical experience. The body is revealed to be an embattled symbol of self-determination and heteronomy. In this struggle between the self and an external force for control over the body, the mindful body is subject to violent deformation. The self, which otherwise serves as a resource for resistance and survival, is violated and, in the most extreme cases, destroyed.

Given music's role in constructing the self through imprinting and remodeling emotions in the ontologically unstable contact zone, it is clear how music can function as an instrument of violence. The following two sections of this article will use examples from the Sachsenhausen concentration camp and the Auschwitz-Birkenau extermination camp to explore this function in more detail. Forced singing and playing were not exclusive to these two camps; numerous examples can be found in the other Nazi camps as well. This article focuses on Sachsenhausen and Auschwitz-Birkenau for three reasons. First, in the interest of space, I have chosen one example each of two different types of camps: the concentration camp and the extermination camp. These were the two most important types of camps in the Nazi system. They were built for different purposes, which meant that prisoners suffered under different conditions in each. Though I have chosen these two camps as examples, I acknowledge that every camp had its own history and peculiarities, and I will endeavor not to lose sight of that in the discussion that follows. Second, Sachsenhausen was considered by the Nazis-within a short period of time after its opening-to be a model concentration camp. Auschwitz-Birkenau was viewed similarly. They may therefore serve as representative of the camp contexts more generally. Third, the greatest number of available sources are from these two camps. The archives from Sachsenhausen, for example, provide us with a remarkable set of materials related to forced singing. There is also a substantial amount of existing work on the camp orchestras in Auschwitz-Birkenau. My discussion below makes use of these already familiar sources, which I examine from a new perspective, and new archival material that I have uncovered as well as interviews I have conducted with survivors.

\section{Forced Singing in the Sachsenhausen Concentration Camp ${ }^{44}$}

The Sachsenhausen concentration camp, which lies north of Berlin, was built in the summer of 1936. One of the first camps to be established, it was meant to serve as a model for subsequent camps. Not all National Socialist concentration camps served the same purpose, and understanding the intended function of a camp is important if we wish to understand the forms and effects that musical violence had there. Sachsenhausen, along with Buchenwald, Ravensbrück, and Neuengamme (to name the largest of this type), belonged to a group of concentration camps that had been established on German state territory beginning in 1936 and which fell under the control of Theodor Eicke, the head of the Concentration Camps Inspectorate (Inspektion der Konzentrationslager, IKL). ${ }^{45}$ They were intended to be "re-education" camps for people who did not fit into what National Socialist ideology called the "Volksgemeinschaft"

\footnotetext{
${ }^{44}$ This discussion in this section draws on Inge Lammel's collection in the Archive of the Academy of Art, Berlin; published and unpublished materials related to Aleksander Kulisiewicz; Gilbert, Music; and Brauer, Sachsenhausen.

${ }^{45}$ See Johannes Tuchel, Die Inspektion der Konzentrationslager 1938-1945: Das System des Terrors (Berlin: Ed. Hentrich, 2004).
} 
(people's community). Sachsenhausen was considered a flagship camp by the Nazis, and research on music in other concentration camps operated by the IKL demonstrates that all of these camps shared many of the same characteristics. ${ }^{46}$ The structure, organization, and politics of incarceration were similar in all of these camps, for example, as were the conditions of inmates' daily lives. Thus this study's examination of music in Sachsenhausen can provide insight into the conditions and practices not only in Sachsenhausen but also in the other concentration camps located on the territory of the German Reich.

Sachsenhausen was initially built to imprison domestic political opponents, including communists, social democrats, and trade unionists, placing them in what was termed "protective custody" (Schutzhaft). Later it would house people labeled "antisocial” as well as homosexuals and Jehovah's Witnesses. Prisoner demographics began to change in 1938; more than six thousand Jews were imprisoned in Sachsenhausen in the wake of Kristallnacht (Night of Broken Glass), which took place on November 9 of that year. From the outbreak of war in September 1939 onwards, people from all over Europe were deported to Sachsenhausen. Once there, prisoners were subjected to forced labor, working in nearly a hundred satellite camps that had been built around Sachsenhausen or other work sites in the nearby area. In the nine years of the camp's existence, tens of thousands of detainees died as a result of violence, illness, medical experiments, starvation, and murder. ${ }^{47}$

There are numerous documented examples of forced as well as voluntary singing in Sachsenhausen. ${ }^{48}$ I am particularly interested in forced singing for the purposes of the argument I advance here. These incidents of forced singing were all characterized by torture, punishment, and humiliation, but I will divide them into three types based on their primary function:

a) Singing as a form of discipline during marching and roll-calls

b) Singing accompanying situations of physical torture

c) Singing as targeted humiliation of German-Jewish prisoners

\section{A. Singing as a form of discipline during marching and roll-calls}

German prisoner Berthold Quade remembered that the camp commandant, Jakob Weiseborn, assigned a song for each workday, which the prisoners were forced to sing while marching to and from work. ${ }^{49}$ Singing on command was already a common practice between 1933 and 1936 in what we now call the early concentration camps. SS guards used forced singing to discipline prisoners and to demonstrate absolute power during marches to work sites or in the prison yard during roll call. ${ }^{50}$ Singing while marching was a well-established practice more generally that could be traced back to military traditions. This type of singing helped marchers keep a disciplined rhythm, seemed to shorten the distance between work sites and the camp, and was intended to create a positive impression among inhabitants of neighboring villages through which the prisoners' column usually passed.

The first prisoners to be deported to Sachsenhausen, like the first SS guards stationed there, had been transferred from existing camps, such as Esterwegen. Prisoners and SS guards brought with them

\footnotetext{
${ }^{46}$ See Kulisiewicz; Kuna, Hudba na hranici života; Knapp, Frauenstimmen; and Giner, Survivre.

${ }^{47}$ See Günter Morsch and Astrid Ley, Sachsenhausen Concentration Camp 1936-1945: Events and Developments (Berlin: Metropol, 2008); and Günter Morsch, Mord und Massenmord im Konzentrationslager Sachsenhausen: 1936-1945 (Berlin: Metropol, 2005).

${ }^{48}$ For more detailed information, see Brauer, Sachsenhausen and Gilbert, Music in the Holocaust, 99-143.

${ }^{49}$ Quade, Konzentrationslager Sachsenhausen (Potsdam: Archive for federal state Brandenburg, Potsdam, without year) rep. $35 \mathrm{H}, \mathrm{Nr} .29,8$.

${ }^{50}$ Fackler, Des Lagers Stimme, 130-50.
} 
their practices of singing, both forced singing and clandestine singing. The majority of the prisoners in Sachsenhausen's early years (1936 to 1939) were German-speaking. They thus shared with the SS camp guards a history of musical socialization and a common repertoire of popular songs. Most of them had partaken in the bourgeois youth movements of the 1920s and 1930s, such as the Wandervogel, or similar socialist youth organizations. Despite being grounded in different political ideologies, these youth movements shared a repertoire of popular and regularly sung songs. Additionally, the Hitler Youth movement, which arose during the 1930s, adapted songs from the labor movement to create a new song repertoire for its own purposes. In the early years, SS guards in concentration camps would recognize the political songs sung by prisoners, but they considered them their own and to be part of the National Socialist movement. The song repertoire in Sachsenhausen, however, was predominantly made up of popular folk songs that would have been familiar to nearly anyone at this time, such as "Wilde Gesellen," the "Seeräuberlied," and "Hoch auf dem gelben Wagen." German-speaking prisoners therefore faced no difficulty in recalling the words when an SS guard shouted out the title of a popular folk song. Many times, the guards would simply shout "Ein Lied" ("A song"), allowing the prisoners to choose a song themselves.

Recollections of forced singing in the prison yard feature prominently in prisoners' memories of targeted punishment. ${ }^{51}$ Especially after 1939, guards would often demand a song in the evenings after a long and hard day's work. This was the most frequently used instrument for demonstrating their power and for collectively humiliating the detainees in the central site of total power, the prison yard. One can find descriptions of the degrading and energy-sapping ritual of evening singing in nearly every record of memories from Sachsenhausen.

Wolfgang Szepansky, a survivor of Sachsenhausen, emphasized the routine nature of forced singing in the camp:

Whenever it struck his fancy, the camp commander would demand a song. Then a step-ladder would promptly be found for the conductor. He would climb up, announce the title of the song, and then raise his baton. [...] The most popular songs were "Haselnuss" and "Fröhlich sein." In spite of the cheerful text and jaunty melody, it sounded more like a dirge when from the raw throats of tired men the slow and tortuous line would issue forth: "Then let us sing and be cheerful." The eerie sound would carry through the air all the way to Oranienburg. And if it was not found satisfactory, then the group would be interrupted and the song would start again from the beginning. ${ }^{52}$

Detainees experienced the order to sing as a form of violence because it affected their senses of self in a number of ways. If a prisoner was unable to sing, the evening roll calls would be extended. Only when the camp commander was satisfied with the performance of this 20,000-voice choir would he bring the torture to an end-and this decision had almost nothing to do with the real quality of singing. Furthermore, singing drained the inmates' last bit of physical strength. Singing for hours and hours combined with standing at attention in the prison yard, regardless of weather conditions, required energy the prisoners needed in order to survive. This form of torture often caused the fatal collapse of already exhausted prisoners or, at the very least, sped up the process of their wasting away. The survivor Hans Haase described it powerfully: "How often [the SS guard Gustav] Sorge tortured us in the evenings for hours

\footnotetext{
${ }^{51}$ See Brauer, Sachsenhausen, 95-98.

${ }^{52}$ Wolfgang Szepansky, Beitrag zur Dokumentation der Geschichte des KZ Sachsenhausen: Manuskript über seine Häftlingszeit im KZ Sachsenhausen (Berlin, without date, Arbeiterlied Archiv, Sign. 10, 8).
} 
with singing or saluting by doffing our caps. It isn't possible to count how many men died of hunger, cold and wet weather or illness." 53 The command "Ein Lied!" given by the SS guard during roll call aimed at the collective humiliation of the prisoners. The German Jew Hans Reichmann, who was imprisoned in Sachsenhausen in 1938, describes how this collective singing functioned as an effective tool for physical and mental torture:

We didn't sing the "Juvivalera" loudly enough. We didn't feel much like Juvivalera with temperatures as cold as minus five or ten. So we had to sing twice, belting it out, melodically laughing and jubilating. "Juvivalera - ha-ha-ha-ha-ha!" We sang with faces like masks, numb, shadowed already by the dark. How much longer did we have to stay, until the verses were finished? How many songs would he have us yell forth? [...] It was intended to be drudgery, we experienced it as drudgery. If there had been any lingering doubt about their evil purposes, [SS guard] Eisfeld and his henchmen dispersed it. ${ }^{54}$

These incidents represent a reversal of the normal purposes behind the practice of collective singing. The practice had been used, and continues to be used, as a source of recreation and for providing pleasure. The collective singing of cheerful songs, a practice in which all of the prisoners-regardless of nationality, religion, or political belief-had been socialized, was connected in their memories to enjoyable experiences and part of what they considered their cultural practices. We know of at least seven clandestine choirs founded by the prisoners in Sachsenhausen: three Polish, two Czech, one Norwegian, and one Jewish. These groups demonstrate, at least on a superficial level, the importance of collective singing as a strategy for survival. Emotional dispositions, ideals, and worldviews were communicated through singing. ${ }^{55}$

In contrast, singing on command in situations marked by the presence of pain, hunger, illness, fear, and feelings of helplessness made a mockery of the original cultural intent and meaning behind collective singing. This forced musicality was an attempt to ascribe new meaning to the embodied emotional practice of singing. This process was compounded by forcing the prisoners to express positive emotions that were diametrically opposed to the actual emotions they were experiencing at the time. As Reichmann has established, this naturally produced mental anguish. The records of prisoners' memories substantiate the argument I have been making that the context of absolute power in the contact zone of music perception enables the remodeling and restructuring of memories, meanings, and emotions. Pleasure had been replaced by pain, the sense of enjoyment by despair, the feeling of familiarity by fear.

\section{B. Singing accompanying situations of physical torture}

While some German prisoners could consider singing during marching to have been no more than an annoyance or even a helpful aid, this type of response would become increasingly rare after 1939 due to the shift in the demographic composition of the camp population. Early prisoners had nearly all been German, but the beginning of the war brought the deportation of tens of thousands of men from all over Europe to Sachsenhausen. In 1944, less than ten percent of the prisoners were native speakers of German. The overwhelming majority of the inmates were not familiar with the German song repertoire that

\footnotetext{
${ }^{53}$ Hans Haase, Zeugenmeldung an die Staatsanwaltschaft (Bonn: Februar 1956, Archiv Sachsenhausen, Oranienburg, Sign. JD 2/3), 84 .

${ }^{54}$ Hans Reichmann, Deutscher Bürger und verfolgter Fude: Novemberpogrom und KZ Sachsenhausen 1937-1939, ed. Michael Wildt (Munich: Oldenburg, 1998), 211-12.

${ }^{55}$ For a more theoretical discussion, see Kay Kaufman Shelemay, "Musical Communities: Rethinking the Collective in Music," Fournal of the American Musicological Society 64, no. 2 (2011): 349-390.
} 
remained unchanged until 1945. Not knowing the German songs was sufficient in itself to provoke punishment. The detainees would be chastised by the SS guards first for not knowing the songs and then for their inadequate singing (from the perspective of the guards). They could be subject to the so-called Strafsingen. The former political prisoner Adam König recalled this form of punishment:

When the songs accompanying the march weren't sung by the work gang to the guards' satisfaction, then punishment would be meted out at the end of the day's work: Strafsingen (punitive singing) [...] practicing and practicing again the songs that would be sung during the march out and back again. ${ }^{56}$

Learning these songs was one of the first duties assigned to newly arrived prisoners. SS guards often combined this memorization work with sports exercises or physical punishment, as Polish prisoners reported. The SS guard Wilhelm Schubert linked the obligatory rehearsal of German songs with so-called Strafsport (punitive sports). ${ }^{57} \mathrm{He}$ ordered the Polish prisoners to practice the songs while remaining in a crouched position. Prisoners were forced to repeat this exercise again and again until he was satisfied with their singing. ${ }^{58}$ Aleksander Kulisiewicz recalled the particular painfulness of this situation: "It was sadism. The German songs had been nice but they became poisoned by this tyranny. We were forced to sing as if we were pleased, but we hated it." 59 The recorded memories of survivors leave no question about the public dehumanization that was intended and that resulted from this forced singing. But the practice would become even more brutal as time went on.

Forced singing was used by SS camp guards during labor battalions' working hours as well. One such example was the so-called Schuhläuferkommando. The prisoners belonging to this labor battalion had to march around the prison yard in rain or strong winds to test the durability of military-issued footwear. The test course was laid out around the prison yard and dotted with a variety of materials, including stones, crushed rock, gravel, and tar. During the day, prisoners would march 35 to 40 kilometers along this route wearing shoes that were not their own size while carrying an additional load on their backs. At the same time, they were forced to learn songs such as "Weit ist der Weg ins Heimatland," which featured the refrain: "Man lives but once and then no more." From the prisoners' perspective, the songs' lyrics painfully parodied the situation in which they found themselves and forced them to confront the hopeless reality of the camp. The sight of these punishment commandos was permanently etched in the memory of the British prisoner of war Jimmy James: “About thirty Sträftlinge, gaunt, half-starved figures in striped suits were being marched around the area, on their backs were heavy packs containing 30 pounds of bricks; truncheon-wielding, SS-guards ensured that they kept up a smart pace and sang when required to do so." In his study of music in the camps, Aleksander Kulisiewicz described another labor battalion that was called the "Singing Horses":

The unlucky victims were harnessed to a heavily loaded barrow, which they had to pull. As they pulled they bent their bodies forward, their heads stooping low to the ground. Meanwhile

\footnotetext{
${ }^{56}$ Adam König, in an interview with Juliane Brauer, Berlin, April 30, 2004.

${ }^{57}$ For more on sport as punishment, see Veronika Springmann, "Das ist die Moorolympiade: 'Lagersport' als Differenzproduktion in Konzentrationslagern," in Personal und Insassen von Totalen Institutionen - zwischen Konfrontation und Verflechtung, ed. Falk Bretschneider, Martin Scheutz, and Alfred Stefan Weiß (Leipzig: Leipziger Universitätsverlag, 2011), vol. 3 of the series Geschlossene Häuser: Historische Studien zu Orten und Institutionen der Separierung, Verwahrung und Bestrafung, 381-394.

${ }^{58}$ Kulisiewicz, Muzika i Pieśni, German working translation, 3.

${ }^{59}$ Kulisiewicz, Liedermacher im Kampf gegen Faschismus - Kunst im Konzentrationslager - Lieder als Zeugen der Geschichte (Cracow 1975), Berlin Arbeiterlied Archiv, Sign. 2, p. 10.

${ }^{60}$ Jimmy James, Moonless Night: One Man's Struggle for Freedom 1940-1945 (London: Kimber, 1983), 123.
} 
they had to sing as loud as they could. The purpose was to simultaneously destroy muscles, lungs, chest, nervous system and vocal chords. They had to sing marching songs, rapid and lovely melodies, all of this, to enhance their despair. ${ }^{61}$

Kulisiewicz classified this torture as "musical sadism," ${ }^{62}$ which was characterized in his view by a song repertoire that was in "painful contrast to reality." In his writings, Kulisiewicz adumbrates the double nature of singing as torture: its ability, in conditions of absolute power, to destroy prisoners' bodies and, at the same time, to torment their minds. The term "musical sadism" describes exactly how the prisoners experienced these conditions. ${ }^{63}$

\section{Singing as targeted humiliation of German-Jewish prisoners ${ }^{64}$}

A number of Jewish prisoners were killed when SS officers and their supporters pushed about a dozen prisoners into a closet of about two sq. meters floor space. Then all the vents were blocked so that most of the prisoners suffocated. [...] A Jewish inmate, an opera singer with the stage name Alfieri, real name Georg Adler, who was among the moribund inmates and had also been abused, was forced by the SS to sing the song "Es gibt im Volksmund der Märchen viele Zahl." ${ }^{55}$

The murder described above took place in the summer of 1940 in the so-called Jewish barracks at the concentration camp Sachsenhausen. This description, like numerous other examples, testifies to the way music frequently accompanied the torture and death of Jewish prisoners, especially when German-Jewish musicians were among them. There is no doubt that SS leaders treated the Jewish prisoners differently because of deep ideological and cultural prejudices. ${ }^{66}$ Commanding Alfieri to sing as he suffocated to death and forcing Jewish musicians to sing or play the violin while they were being tortured exemplify a particularly violent ritual that was aimed at Jewish inmates.

The use of music in torture has ties to a belief propagated by late-nineteenth-century bourgeois anti-Semites that German-Jewish musicians undermined German musical life and were out to steal Germans' holiest asset: their music. It was based on the conviction that Germans had a special relationship with music, which was one of the primary claims on which the German bourgeoisie based its sense of moral superiority. ${ }^{67}$ The German press had done much to spread this idea more broadly among the German public, making it somewhat natural that German guards' in Sachsenhausen would then use music specifically to humiliate Jewish musicians. The former prisoner Willy Rheder related the following incident, which took place in the prison yard: "I know from personal experience that this Jewish opera singer had to sing on the parade ground on the orders of Kaiser [SS Sergeant Otto Kaiser] and was assaulted by Kaiser with punches and kicks. Kaiser had particular fun in making this singer repeatedly sing

\footnotetext{
${ }^{61}$ Kulisiewicz, "Dalsze przyczynki do zagadnień psychopatologii muzyki,” 40.

${ }^{62}$ Ibid.

${ }^{63}$ I was reminded of Kulisiewicz's idea of "musical sadism” by Barbara Milewski and Bret Werb in their joint paper, "A Little Known Study of Musical Sadism" delivered at the "Music in Detention" conference held in Göttingen on March 15 and 16, 2013.

${ }^{64}$ Jewish prisoners in Sachsenhausen were mostly German-Jewish. I can therefore say very little about the specific suffering of Jewish prisoners from other countries, as their experiences are not reflected in the sources available to me.

${ }^{65}$ Final Verdict in the Case against Gustav Sorge and Wilhelm Schubert: On the Mass Murders Committed by the Accused Gustav Sorge, Bonn District Court, State Attorney's Office. Bonn, February 6, 1959: Archive of Sachsenhausen Museum, Sign. JD 2/50, 111 .

${ }^{66}$ See more examples in Brauer, Sachsenhausen, 297-300.

${ }^{67}$ Celia Applegate and Pamela Potter, Music and German National Identity (Chicago: University of Chicago Press, 2002); and Deutsche Meister - böse Geister?, ed. Hermann Danuser (Schliengen: Ed. Argus, 2001).
} 
arias while he was being assaulted. He characterized the singing as squeaking." ${ }^{68}$ We can see in the details of this account the influence of what musicologist Ruth HaCohen has called the "music libel against the Jews." ${ }^{69}$ Drawing on a large number of literary and musical sources, HaCohen demonstrates that Jews were considered to be "noisemakers" as far back as the early Christian period. This characterization remained current in Western Europe into the early twentieth century. In the Christian imagination, Jewish music, perceived as "noise," was associated with disharmony. Western European music was considered superior, morally good, genuine, deep, and holy. The rise of German nationalism in the nineteenth century turned this centuries-old opposition between "Jewish noise" and "Christian harmony" into a more generalized anxiety regarding Jewish music. This, along with the Romantic notion held by bourgeois Germans of belonging to a musically gifted people, meant that any discussion of German-ness and music would necessarily involve questions of nationalism, national identity, and power. ${ }^{70}$ Jewish musicians were perceived by German ideologues as a concrete threat, and they attributed the successful careers of Jewish musicians not to those musicians' talents, but to the collusion of a network grounded in and united by a "Jewish tradition." 71

With the rise of National Socialism, modern anti-Semitic ideas were transformed into concrete actions: Jewish musicians first lost their work, then they were persecuted, exiled, and exterminated. But this was not all. Music was used in the concentration and extermination camps to torture these musicians in additional ways. In using music, the camp guards sought to destroy a key aspect of German-Jewish cultural identity. ${ }^{72}$ We must assume that these experiences provoked a painful rupture in German-Jewish self-understanding. The disappearance of German-Jewish music and musicians from German society and the devastating injury of German-Jewish musicians' sense of self were not the only effects. In associating music with torture, pain, and death, the SS robbed German-Jewish musicians of a vital resource for their own survival. ${ }^{73}$

What conclusions can be drawn from these varied examples of forced singing in the Nazi concentration camp? It is important first to differentiate between nationalities and social groups among the prisoners. German-speaking prisoners possessed a cultural ability to cope with the order to sing that was not enjoyed by the others. Whereas the primary function of forced singing during the first three years of the camps' existence was to organize and accompany daily life, the aims and impact changed with the beginning of the war in 1939. SS guards used forced singing more purposefully to torture, punish, and humiliate all prisoners. But it could also be used in particular ways to humiliate Jewish musicians specifically. These practices of forced singing were motivated by a desire not only to punish the prisoners' physical bodies, but to break them inwardly, to destroy the certainty of their memories, identities, and humanity.

\footnotetext{
${ }^{68}$ Willy Rheder, Zeugenaussage (Landeskriminalpolizeidienststelle Stada, 16.06.1961), AS JD 7/8, 55.

${ }^{69}$ Ruth HaCohen, Music Libel against the Jews (New Haven: Yale University Press, 2011).

${ }^{70}$ Eckhard John, Musikbolschewismus: Die Politisierung der Musik in Deutschland 1918-1938 (Stuttgart: Metzler, 1994); Applegate/Potter, Music and German; Annkatrin Dahm, Der Topos der Fuden: Studien zur Geschichte des Antisemitismus im deutschsprachigen Musikschrifttum (Göttingen: Vandenhoeck \& Ruprecht, 2007), and HaCohen, Music Libel.

${ }^{71}$ Hans Koeltsch, "Das Judentum in der Musik," in Handbuch der Fudenfrage, ed. M. Fritsch (Leipzig, 1933), 316-17.

${ }^{72}$ For more, see Juliane Brauer, "Singing for Life and Death: Jewish Prisoners at Sachsenhausen Concentration Camp," in Voices of Displacement: Music and Memory in the German Fewish Experience in Modernity, ed. Yael Sela-Teichler and Philip V. Bohlman (forthcoming in 2016).

${ }^{73}$ See the example of the German-Jewish musician Peter Bach: Juliane Brauer, "Peter Bach," in Lebensspuren: Biografische Skizzen von Opfern der NS-Tötungsanstalt Hartheim, ed. Florian Schwanninger and Irene Zauner-Leitner (Innsbruck: Studienverlag 2013), 87-90.
} 
While forced singing appears often in survivors' memories of IKL-run concentration camps, it more rarely features in recorded memories of survivors of extermination camps, which were all built in 1941 and 1942 in what today are Poland and Belarus with the express aim of exterminating hundreds of thousands of European Jews. In these extermination camps, music and torture coexisted most obviously in the form of the prisoners' camp orchestras, which played on the order of camp guards. While the Auschwitz-Birkenau camp orchestras are particularly well known, research over the past twenty years has identified prisoners' orchestras in nearly every Nazi camp, regardless of type. There is, however, relatively little information about the prisoners' orchestras in Bełżec, Sobibór, or Treblinka, ${ }^{74}$ especially compared to the available material related to the largest extermination camp, Auschwitz-Birkenau. One reason for the lack of material from the other extermination camps may be that there were very few survivors, since Jews were gassed immediately upon arrival in these camps. Auschwitz-Birkenau, though, was also a concentration camp, in which hundreds of thousands of prisoners were housed in barracks to work for SS enterprises. There was thus something resembling routine daily life even under conditions of total terror and arbitrary death. The large number of published memoirs and scholarly studies allows us to begin to make sense of how music and torture worked together in this camp, in spite of the difficulties inherent in any attempt to explain conditions that are nearly unfathomable. ${ }^{75}$

\section{Camp Orchestras in Auschwitz-Birkenau}

In 1941 Auschwitz-Birkenau was built some three kilometers away from the main camp of Auschwitz as a concentration and extermination camp. The following year, gas chambers and crematories were installed for the express purpose of killing hundreds of thousands of people with murderous efficiency. The camp was divided by electrical fences into separate areas for women, men, Romani peoples, and prisoners from Theresienstadt. Over 400,000 prisoners were registered as laborers, and nearly half died. ${ }^{76}$ Up until the end of 1944, more than one million people, predominantly Jewish deportees, were murdered here. ${ }^{77}$

Each of the camp areas in Birkenau had its own prisoners' orchestra. The Jewish men's and women's orchestras are the best documented. The first of these camp orchestras was founded in the men's sector in the summer of 1942 on the order of the SS camp commander. Then in April 1943 a prisoners' orchestra was formed in the women's sector. ${ }^{78}$ It was conducted by the violinist Alma Rosé, Gustav Mahler's niece. ${ }^{79}$ Members of the orchestra were housed in special barracks, which resulted in better living conditions in

\footnotetext{
${ }^{74}$ For more details, see Gilbert, Music, 192-94, and Annkatrin Dahm, "Musik in den nationalsozialistischen Vernichtungszentren Bełżec, Sobibór und Treblinka," Musica reanimata 23 (1997): 1-11. See also http://www.deathcamps.org/reinhard/arsongs.html.

${ }^{75}$ For example, see Gilbert, Music; Knapp, Frauenorchester; Hans-Ludger Kreuzheck, “'Kapellen der Hölle’: Die offiziellen Lagerkapellen in Auschwitz und anderen Konzentrationslagern," Part 1, Musik von unten: Verein für demokratische Musikkulturen in Geschichte und Gegenwart Informationsblatt 8, no. 17 (1995): 33-44; Ibid., Part 2, Musik von unten 8, no. 18 (1995): 28-43; Ibid., Part 3, Musik von unten 8, no. 19 (1995): 3-23. Memoirs include Stroumsa, Violinist; Laks, Music; Fenelon, Playing; Lasker-Wallfisch, Inherent.

${ }^{76}$ Franciszek Piper, "The Number of Victims," in Anatomy of the Auschwitz Death Camp, ed. Yiśra el Gutman and Michael Berenbaum (Bloomington: Indiana University Press, 1994), 71.

${ }^{77}$ See Gutman and Berenbaum, Auschwitz Death Camp; Laurence Rees, Auschwitz: A New History (New York: Public Affairs, 2005); Sybille Steinbacher, Auschwitz: A History (New York: Ecco, 2005).

${ }^{78}$ For more on the history of the women's camp, see Irena Strzelecka, "Women," in Anatomy of the Auschwitz Death Camp, ed. Yiśra'el Gutman and Michael Berenbaum (Bloomington: Indiana University Press, 1994), 393- 411. For more on the women's orchestra, see Knapp, Frauenorchester.

${ }^{79}$ Richard Newman and Karen Kirtly, Alma Rosé: Vienna to Auschwitz (Portland, OR: Amadeus Press, 2000).
} 
comparison to other prisoners. These barracks were not overcrowded, and the musicians occasionally received supplementary food rations as a form of "reward" for their work. Because high-ranking SS officers had nearly daily contact with the orchestras, the musicians were afforded better clothing and had more frequent opportunities to bathe and attend to personal hygiene.

The orchestras' primary duty in Auschwitz-Birkenau was to structure daily life by accompanying quotidian camp procedures. However, there were crucial differences between the men's and women's orchestras. ${ }^{80}$ Male musicians were forced to play in the orchestra in addition to working in labor battalions. This double burden led to a sense of desperation, physical illness, and even death among orchestra members. Given the brutal logic of the camps, these deaths did not at all trouble the SS. Male musicians were easily replaced; new prisoners arrived every day from all over Europe, and trained musicians could always be found among them.

Finding musicians was a more difficult task for Maria Mandl, the head (Oberaufseherin) of the women's camp. There tended to be fewer women among the deportees who could play an instrument, and those that could were frequently not as well trained as the male musicians. In order to satisfy the demands of the camp administration, the women musicians were forced to spend all day practicing in their barracks. For this reason, the women's orchestra could be called on by the SS to play at any time. ${ }^{81}$ Keeping these differences in mind, I will divide my examination of the specific violence associated with instrumental music in Auschwitz-Birkenau into three sections:

a) The playing of music as an experience of violence

b) The hearing of music as an experience of violence

c) The command to play music as a form of violence: the perspective of the SS

\section{A. The playing of music as an experience of violence}

Survivors' recollections about music in Auschwitz tend to cluster around two types of events: the music provided by the orchestras at the entrance gate every morning and evening, and the musical "welcome" that greeted newly arrived prisoners on the ramp. Both the men's and the women's orchestras were compelled to provide music at the entrance gate. Playing for new arrivals, however, was the duty of the women's orchestra alone, because the female musicians were always available. The Polish survivor Seweryna Szmaglewska remembered one such occasion: "And the night concert begins. Shouts of the SS men, moans of the beaten, crying children coming from railroad cars mix with the melodies of Spanish dances, serenades, and sentimental songs." ${ }^{82}$ Musicians' reactions to the situation varied. But what is recalled most often is the specific sense of despair associated with the occasion. They were not only forced to witness the event again and again, but they were forced to accompany it with their music, too. In her memoirs, the musician Esther Bejarano, who had been deported to Auschwitz-Birkenau in 1943, emphasizes this "enormous psychic strain":

After some weeks we received the command to stand and play music at the camp gate as the trains were arriving. For us musicians this was particularly bad. We knew that all the people who streamed out of the wagons were going to the gas chambers. And we had to play pleasant

\footnotetext{
${ }^{80}$ For more detailed analyses, see Knapp, Frauenorchester.

${ }^{81}$ For more information, see Gilbert, Music, 179-82.

${ }^{82}$ Seweryna Szmaglewska, Smoke over Birkenau (New York: Holt, 1947), 287; The book first appeared in Polish as Dymy nad Birkenau (Warszawa: Czytelnik, 1945).
} 
music for them. ${ }^{83}$

The Polish musician Halina Opielka described the newly arrived prisoners' reactions to this "musical greeting":

Many of them [the newly arrived prisoners] listened eagerly to the music. Some even greeted the sounds with movements of their own bodies. The sight of the women's orchestra calmed them somewhat perhaps, gave them courage and hope that this place where they had just arrived could not be too terrible if they were being "greeted" by an orchestra. ${ }^{84}$

This is a prime example of the ambiguity inherent in music and its effect. It is possible enough to believe that the music provided by the women's orchestra calmed the newly arrived deportees, reassured them and made the horror of their arrival in Birkenau somewhat more tolerable, even if it only served to hide the fact that they were on their way to their deaths. The musicians who witnessed this contradiction and felt it viscerally suffered greatly from this experience of their music, which was drawn from the widely known and loved classical orchestral and operetta repertoire. Their beloved music had been repurposed into a small $\operatorname{cog}$ in the larger wheel of the camp's machinery of death.

This led the youngest Polish woman in the orchestra, for example, to ask the camp commander to remove her from the musicians' barracks. Unable to say that she was morally distraught by her musical duties, she named "mental and physical exhaustion" as the reason for her request, according to the musician Helena Dunicz-Niminska. The latter emphasized how distressing forced labor in the music commando (Musikkommando) was and the nervous tension it provoked. ${ }^{85}$ In her chapter on Auschwitz, Shirli Gilbert refers to the case of a Greek double bass player who would always break down in tears when she saw new prisoners arrive. When she was caught crying, an SS officer reminded her that "it was forbidden to cry, and threatened to dispose of anyone who behaved in this manner." 86

Music played during the marches out and back in again through the entrance gate, the "holy place of power," was used to demonstrate the absolute power held over inmates' bodies, the ability to cause them untold pain and humiliate them entirely. The musicians experienced and described a moral pain, which was remembered as guilt and shame, as recalled in an interview with a Jewish musician: "Every time I thought to myself, my god, what are you actually doing here? You play whereas the other must do hard work. One always had the feeling that one had done something wrong. One had this feeling of guilt." ${ }^{" 77}$ Esther Bejarano also remembered the great desperation and sadness she experienced while playing at the entrance gate, mainly during the marches back into the camp in the evenings:

When they left for work, that was not so awful. But when they came back, and you saw these people, many of whom had to be propped up, held because they could hardly walk on their own. That was terrible for us. We stood there with tears in our eyes. We cried and told ourselves again and again: my God, if we were not doing this, we would be going to the gas.

\footnotetext{
${ }^{83}$ Esther Bejarano, "Man nannte mich Krümel”: Eine jüdische fugend in den Zeiten der Verfolgung (Hamburg: Curio, 1989$), 23$.

${ }^{84}$ See the Opielka interview in Knapp, Das Frauenorchester, 229.

${ }^{85}$ Quoted in Stanisław Kłodziński and Jan Malowski, "Vernichtung durch Arbeit: Zur Pathologie der Arbeit im Konzentrationslager," in Die Auschwitz-Hefte: Texte der polnischen Zeitschrift Przeglad lekarski über historische, psychische und medizinische Aspekte des Lebens und Sterbens in Auschwitz, ed. Hamburger Institut für Sozialforschung, vol. 2 (Weinheim: Beltz, 1987), 135-47, esp. 144-5. This Polish journal referred to is Przeglą lekarski: Organ Towarzystwa Lekarskiego Krakowskiego, Oddzia·lu PTL, Cracow.

${ }^{86}$ Gilbert, Music, 178.

${ }^{87}$ Gabriele Knapp, "Das Frauenorchester von Auschwitz Birkenau: Bewältigungsformen musikalischer Zwangsarbeit,” Musik von unten: Verein für demokratische Musikkulturen in Geschichte und Gegenwart Informationsblatt 8, no. 9 (1995/1996): $17,27$.
} 
Yes, it was an order directly from the SS - we had to play. ${ }^{88}$

The coercion involved in playing music broke the women; they sank into depression, could no longer play, could not eat anything, and had to be hidden by the other prisoners. The stress of keeping the instruments in working order, reading notes, producing acceptable sound on icy days while wearing flimsy clothing, battling hunger, illness, and fatigue, all combined with the knowledge that playing the wrong notes could be lethal: this was incontrovertibly a form of forced labor, as Gabriele Knapp has already pointed out. ${ }^{89}$ I argue that the violence inflicted in forcing these musicians to play music was of an even greater degree. It purposefully attacked a musician's identity. This form of music-making destroyed previously held certainties and destabilized memories from the musicians' former lives, in which music was tied to happiness, a sense of luck and compassion for humanity.

The sociologist Maja Suderland has shown that cultural identity could serve as a resource for survival in the concentration camps. ${ }^{90}$ Suderland emphasizes that knowledge and "cultural capital" could not be stolen from the prisoners at the camp's entrance gate in the same way that private property, clothing, or even their hair was. Therefore, Suderland explains, prisoners could and did use their knowledge and cultural capital as resources for survival. I argue, however, that the destructive effects of these new experiences of music in the camps left musicians unable to draw on their cultural identities, skills, and knowledge as a means to help them survive. The orders by the camp guards to play music contrasted in an extreme way with the habitual practices of music performance and with the musicians' own emotional expectations. Aside from the military marches played at the entrance gate, the repertoire was a cross section of music that would have been played in contemporary Central European concert halls: compositions by Robert Schumann, Franz Schubert, Johann Strauss, Johann Sebastian Bach, Ludwig van Beethoven, or Johannes Brahms, arias by Gioachino Rossini, Giacomo Puccini, or Giuseppe Verdi, and popular operettas. The musicians, most of whom were not professionals, had played these compositions in their former lives at private evening concerts, for their own pleasure, or for friends and family members. This kind of music was linked with feelings of well-being, security, and happiness. It formed part of the musician's cultural identity and provided a sense of self-assurance. Being forced to play these same pieces in the extermination camp led to a painful disruption in musicians' identities, a break with their internalized manners, expectations, and emotions. Esther Bejarano describes in an illustrative way this process of losing one's own past and concurrently losing music as a resource for mental resistance: "Music was no longer a pleasure. We played only because of the order, never for ourselves. I had always liked to sing, but singing was spoiled for me in Auschwitz." ${ }^{91}$ There were physical repercussions to this association of music with compulsion and with the horrific scenes in the camps. The conductor of the men's orchestra in Birkenau described the fatigue and incidents of suicide in the orchestra:

Apart from a few privileged persons, everyone went out to work just as before and returned in a state of extreme physical and mental exhaustion. Some managed to endure this, while others broke down completely. Some drew themselves on the wires. The size of the orchestra

\footnotetext{
${ }^{88}$ Quoted in Katarzyna Naliwajek-Mazurek, "Music and its Emotional Aspects during the Nazi Occupation of Poland," in Besatzungsmacht Musik: Zur Musik- und Emotionsgeschichte im Zeitalter der Weltkriege (1914-1949), ed. Sven Oliver Müller and Sarah Zalfen (Bielefeld: Transcript, 2012), 207-226, esp. 222.

${ }^{89}$ Knapp, Frauenorchester.

${ }^{90}$ Maja Suderland, Territorien des Selbst: Kulturelle Identität als Ressource für das tägliche Überleben im Konzentrationslager (Frankfurt a. M.: Campus, 2004).

${ }^{91}$ Esther Bejarano, "Das Singen ist mir in Auschwitz vergangen," Kontrapunkt 2 (1989): 18.
} 
changed almost from day to day and in time shrank catastrophically. ${ }^{92}$

In this extraordinary and absolutely changed contact zone of music, in a situation marked by murder, humiliation, and torture, new emotions were generated among the musicians, including rage, despair, and shame. There was the stress associated with the fear of failing in the eyes of the SS guards too. These new negative emotions impressed themselves in the self and redefined the musician's relationship with music. In the situations described above, we see how music attacked the body, deconstructed musicians' identities, and caused physical exhaustion and illness. It is clear that music, with its strong links to memories, emotions, and identity, has the potential to destroy the mindful body as defined above. This is perhaps why, in contrast to what we find in recorded memories from other camps such as Sachsenhausen, there are hardly any recollections from Auschwitz-Birkenau of music giving comfort or aid.

\section{B. The hearing of music as an experience of violence}

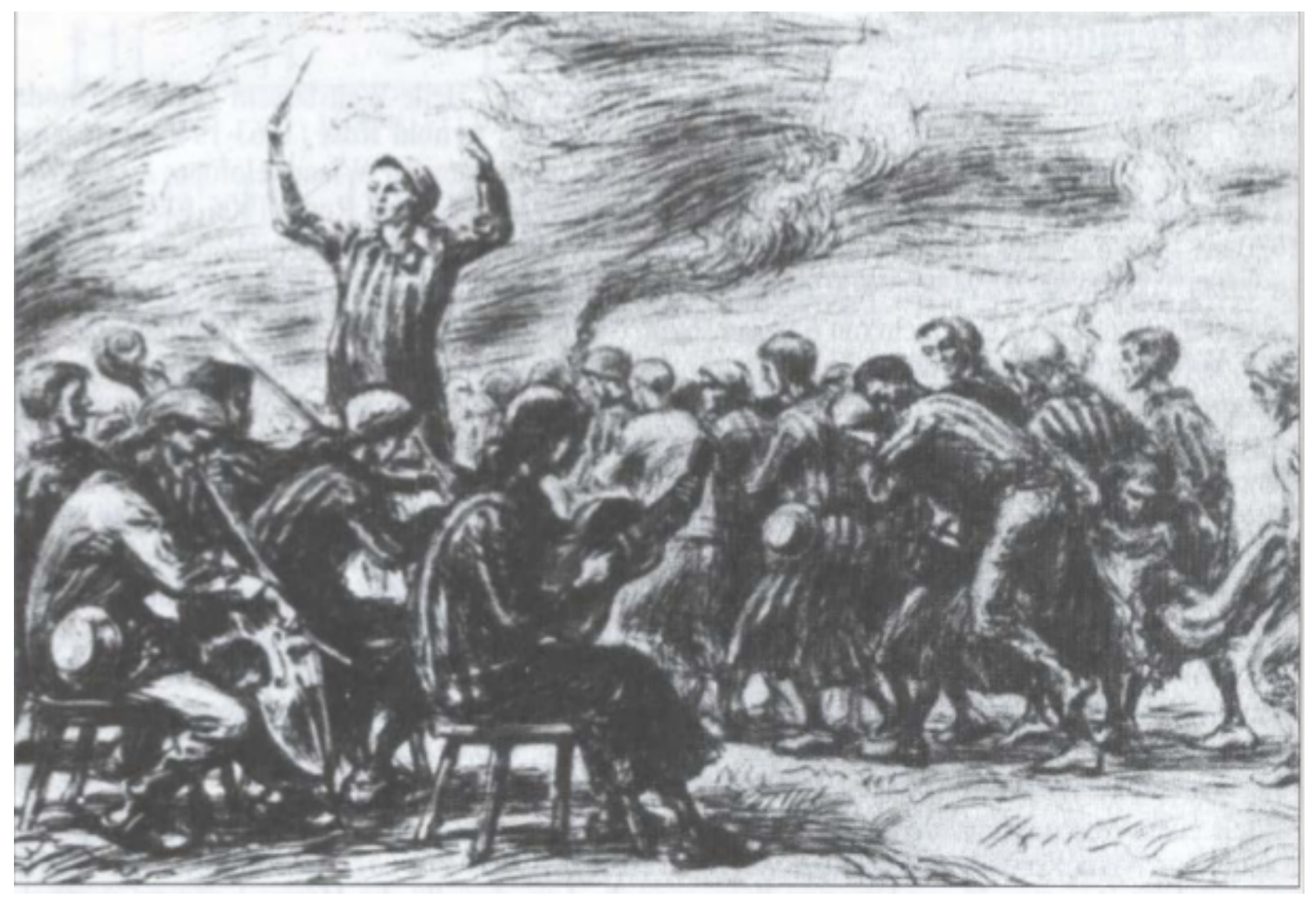

Illustration 1: Women’s orchestra, Auschwitz-Birkenau, drawing by Mieczysław Kościelniak, $1944^{93}$

It is exceedingly rare to find survivors' reports that do not mention music being played at the entrance gate to Auschwitz-Birkenau. The camp orchestra stood at the gate, rain or shine, morning and

\footnotetext{
${ }^{92}$ Laks, Music, 47.

${ }^{93}$ Drawing by Mieczysław Kościelniak, around 1944, http://denktag2006.denktag-archiv.de/typo3temp/pics/4f904e3a1e.jpg, accessed September 20, 2013. This picture now firmly belongs to the cultural memory of the camps. It served, for example, as the cover illustration for the pamphlet produced by the office of the president of the state parliament of Rhineland-Palatinate to accompany the events marking the Day of Remembrance for the Victims of National Socialism on January 27, 2006.
} 
night, during the departure and arrival of the work gangs, playing well-known marches or other pieces. The scene has become representative of the misery of the camp and the "rupture in civilization" 94 that the camp embodied. Drawings by prisoners, such as the well-known one by Mieczysław Kościelniak, captured the scene for posterity. Photographs of the camp orchestra at the entrance gate ${ }^{95}$ are among the earliest media products from the concentration camps and have thus served as an enduring visual motif in popular historical culture and collective memory. ${ }^{96}$

The description provided by the Auschwitz survivor Mali Fritz serves as an illustrative example of survivors' memories of the terribly destructive effects that playing this type of marching music had on prisoners:

The SS guards like the music at the gate. The prisoners were tortured by it. They only want to demonstrate how strongly they have a handle on inmates [...] This cursed music, like a satisfied grunt hanging over these circumstances. During the march into the camp, this madhouse music. They really try to play the measure! Why, oh why? Our ghostlike column must look as though it were coming up from the bowels of the earth. And left, and left, and left two three ... This cursed measure of fear. ${ }^{97}$

The marching rhythm works as an extension of the SS guard's will. Fritz called music a "satisfied grunt," by which he meant a grunt as would be emitted by an SS guard. The guard and the sound complemented each other. Primo Levi, too, made reference to the most obvious function of military marches at the camp entrance gate, which was the symbolic center of absolute power. Music that was played at the order of the SS had the power to discipline the prisoners' destroyed bodies, as Primo Levi recalled:

When this music plays we know that our comrades, out in the fog, are marching like automatons; their souls are dead and the music drives them, like the wind drives dead leaves, and takes the place of their wills. There is no longer will: every beat of the drum becomes a step, a reflected concentration of exhausted muscles. ${ }^{98}$

Absolute power aims not only to control prisoners' physical bodies, but also to destroy the mindful body, to dehumanize the prisoners so that they are nothing more than "automatons." Music played a key role in this process, robbing the detainees of feelings and a sense of their own will before they finally succumbed to death.

The infirmary was another site of forced playing of music. The camp commander would send musicians to perform there, usually shortly before a selection for the gas chamber was to be made. Musicians thus functioned as harbingers of death. Szymon Laks relates one such occasion that took place in the winter of 1943, in which the camp commander ordered Dutch musicians to play Christmas carols in the infirmary to mark the holiday. The predominantly Jewish prisoners undoubtedly felt humiliated as the

\footnotetext{
${ }^{94}$ The term is taken from Dan Diner: "Rupture in civilization': On the Genesis and Meaning of a Concept in Understanding," in On Germans and Fews under the Nazi regime: Essays by Three Generations of Historians; A Festschrift in Honor of Otto Dov Kulka, ed. Moshe Zimmermann (Jerusalem: Hebrew Univ. Magnes Press, 2006), 33-49.

95 "Prisoners' orchestra during a Sunday concert for the SS-men in Auschwitz. The orchestra was probably conducted by the inmate Franciszek Nierychlo. [Photograph \# 81216]," 1941, accessed September 20, 2013,

http://digitalassets.ushmm.org/photoarchives/detail.aspx?id=12074\&search=\%2381216\&index =1; "Camp orchestra," picture taken by the SS, 1941, accessed 19 December 2014, http://en.auschwitz.org/m/index.php?option =com_ponygallery\&func=detail\&id=1149\&Itemid=3.

${ }^{96}$ Orchestras are also present in the well-known American TV series Holocaust, directed by Marvin J. Chomsky (Hollywood: Paramount Home Entertainment, 1978; DVD 2008). There is also reference to the orchestra in Art Spiegelman's historical graphic novel: Maus: A Survivor's Tale I: My Father Bleeds History (New York: Pantheon Books, 1986).

${ }_{97}^{97}$ Mali Fritz, Essig gegen den Durst: 565 Tage in Auschwitz-Birkenau (Wien: Verlag für Gesellschaftskritik, 1986$), 22$.

${ }^{98}$ Levi, If This Is a Man, 57.
} 
orchestra filled the ward with the sound of German Christmas carols. A number of the patients reacted "with crying and sobbing in response to the unexpected music." It was "as if they could not believe that it was really happening," Laks writes. He recalled how helpless the musicians themselves were in the face of this emotional response. They were then forcibly ejected by the ill inmates: "From all sides spasmodic cries, ever more numerous, ever shriller [...] Enough of this! Stop! Begone! Clear out! Let us croak in peace!" 99

The recollections of the violinist Jacques Stroumsa of a similar incident in the infirmary describe a markedly different scene. He remembers his fellow inmates' effusive response to his performance of Mozart's Sonata in A Major. Even thirty years after the camp's liberation, fellow former prisoners would enthusiastically embrace him when they met. ${ }^{100}$ To understand the difference between these two recollections of fellow inmates' responses, we must return to the idea of the mindful body. Szymon Laks' memories are generally characterized by a focus on situations of musical violence. He explains why he accentuates this aspect:

There are many publications that claim, not without a certain emphasis, that music kept up the spirits of the emaciated prisoners and gave them the strength to survive. Others assert that music had a directly opposite effect, that it demoralized the poor wretches and contributed instead to their earlier demise. I personally share the latter opinion. ${ }^{101}$

For Szymon Laks, it is the memories of musical violence that predominate. It will be those types of occurrences and shades of meaning that will be inscribed in his recollections. Jacques Stroumsa, on the other hand, always describes the violin and music as central to his survival in the camp. It is therefore hardly surprising that positive emotions generated by the experience of music had inscribed themselves on his social body and had thus become interwoven in the patterns of his memories. It is the mindful body that ascribes meaning to music and inscribes new associations onto musical memories based on new experiences. If we consider each man's general disposition toward music in the camps, which they describe explicitly, it becomes clear how negative and affirmative stances, in Laks' and Stroumsa's cases respectively, are reflected in the incidents that are remembered and how they are remembered.

Survivors' memories of the orchestras tend to emphasize the acoustic immediacy of music, their inability to avoid it, resist the rhythm, or physically close their ears to it. The inmates were forced to hear and perceive music against their own will. The ear reveals itself to be a particularly vulnerable sensory organ, which makes it a key component in music's ability to work in violent ways. The ear is vulnerable because a person is unable to turn off his or her hearing, to voluntarily interrupt the perception of the world through the ear. Because sounds and noises may thus make their way unimpeded into the person's mind, she finds herself open to violation by way of her ear.

Absolute power proved itself to be subtle, though in no way inefficient, in how it exerted control over the mindful bodies of prisoners. SS guards were not limited to assaulting the physical body, harming the prisoner in a material way; they were able to inscribe negative emotions onto the body, such as fear, pain, rage, and helplessness. These emotions arose in contexts of coerced mechanical marching to a prescribed rhythm, accompanied by arbitrary violence and death meted out by the SS, and through hearing music that, in stark contrast to the immediate situation, could have had positive memories associated with it.

\footnotetext{
${ }^{99}$ Laks, Music, 99.

${ }^{100}$ Stroumsa, Violinist, 48-9.

${ }^{101}$ Laks, Music, 5.
} 
Given music's especially close relationship to learned attitudes and emotions and its ability to prompt memories and therefore aid in reinforcing one's sense of identity, camp experiences in which detainees were forced to listen to music resulted in a special kind of despair. Some of the prisoners were shattered psychologically by the stark contrast between positive memories of a happier past and the negative emotions created by the concrete experience of music in the camp. This purposeful assault against the social body ends in pain and despair: despair at the loss of dignity, one's identity as a person, one's past, and-in the end-hope for the future. "Despair is not weakness on the part of a will that no longer knows what is to become of itself," Wolfgang Sofsky writes, "but the fragmentation of corporeal self-awareness. And it is not limited to a single moment, but is instead an overwhelming, unstoppable encroaching pain." ${ }^{102}$ This inner fragmentation became realized in the external world when the physical body finally gave up, having lost the last of its will to survive.

\section{The command to play music as a form of violence: the perspective of the SS}

There are serious difficulties in any attempt to determine the perspective of the SS guards because no records of their thoughts have survived. This section will thus use the considerations discussed above as well as camp survivors' recorded memories to attempt to reconstruct the motivations and responses of SS guards in giving orders for prisoners to play music

The camp orchestras in Auschwitz-Birkenau performed at several types of representative functions: visits by high-ranking figures, camp commanders' birthdays, and Sunday afternoon concerts in the camp yard. These performances were attended by SS guards (seated in chairs) and prisoners (standing in lines). In addition, the musicians were forced to play for and at the pleasure of higher-ranking SS guards. Though the guards could demand a performance at any time day or night, requests for their favorite compositions came most frequently after they had taken part in mass killings. Because members of the women's orchestra were always present in the camp and "always had to be ready to play," as Lasker-Wallfisch writes, the task most often fell to them. ${ }^{103}$ Helena Dunicz-Niwinska, too, recalled these performances:

The horrible, drunken screams of the SS guards, and the cry: Bring in the band! Play! In the evening (after they had completed their work in the two crematoriums located nearby), SS guards demanded music, so they could "relax" in the block leader's barracks rooms: the connoisseurs among them would choose works by Grieg, Schumann and Mozart. ${ }^{104}$

As in other cases discussed thus far, the use of music in these episodes has much to do with individual habits and practices. We can therefore imagine that SS guards ordered music to be played for therapeutic reasons and as a form of distraction. ${ }^{105}$

However, distraction is not the only explanation for the guards' demands for music. One of the most well-known examples of a cultured SS member is the doctor Joseph Mengele, who worked in Birkenau and who was often described as well educated and a music enthusiast. In survivors' memories he is often remembered standing at the platform whistling well-known arias while selecting newly arrived deportees to be sent to the gas chambers. And it is known that he enjoyed relaxing after he had completed his "work" by listening to compositions by Robert Schumann or Franz Schubert. ${ }^{106}$ Gilbert explained in a general way

\footnotetext{
102 Sofsky, Traktat, $76 f$.

${ }^{103}$ Lasker-Wallfisch, Inherent, 79.

${ }^{104}$ Quoted in Kłodziński and Malowski, “Arbeit,” 145.

${ }^{105}$ See also Moreno, "Orpheus in Hell," 271

${ }^{106}$ Fania Fenelon, interviewed in Niklas Frank, "Nach Mord Schumanns Träumerei," Stern 33, 1980, $280-283$.
} 
how music was used to present a certain impression of Germans and German culture: "Above all, it [music] provided a framework within which the SS could maintain a self-image of refined German culture and personal 'decency,' not apart from but precisely in the context of the activities in which they were involved." ${ }^{107}$ I agree, and I furthermore argue that this cultivated "enjoyment" of music was intended to demonstrate moral superiority and, on some level, a sense of normality. This bourgeois notion of music was based on the German Romantic understanding of music as something good, moral, and beautiful, a means of producing and solidifying a sense of ethics. The SS reproduced bourgeois customs related to music as well as the classical repertoire in these private concerts and Sunday afternoon concerts in the yard. By fostering this habitus, the SS styled itself as an organization composed of cultured, civilized, and educated people, which was contrasted directly with the image of the humiliated prisoners. The very same music would be used by the music aficionados of the SS to rob the prisoners of their humanity and destroy their identities. Music had a dual purpose for the SS: to shore up their own sense of self while destroying that of the prisoners.

\section{Music and Torture / Music as Torture}

As is evident from the examples provided here, music was systematically used in concentration camps to accompany torture and as an instrument of torture itself. Music was purposefully fashioned into a form of "cruel, inhuman and degrading treatment or punishment." Though the term did not exist at the time, music in the Nazi camps was plainly a type of "no-touch torture." 108 This "modern system of torture" 109 combines "sensory disorientation'-isolation, standing, extremes of heat and cold, light and dark, noise and silence-with self-inflicted pain, both physical and psychological, so as to cause a prisoner's very 'identity to disintegrate." 110 This description fits how music was related to the prisoners' pain and anxieties and the perpetrators' motivations and behavior in conditions of absolute power as described here.

The use of music was so fruitful a technique that SS guards changed how they used music to accommodate changes in the camp population, as has been demonstrated by the example of singing in Sachsenhausen. We can begin to make sense of why they did so even without ego-documents from members of the SS. Informed by the Romantic conceptualization of music, SS officers, some of whom were well educated, used music to demonstrate their own superiority and refinement. In a similar way, but with opposite effect, the guards tortured prisoners with music to purposefully deconstruct their cultural identities. Prisoners' beliefs about music's relationship with concepts of humanity and morality were to be destroyed. In conditions of absolute power, culture served as a means to define belonging. In the perverse logic of the SS, music in this context worked to determine who counted among the civilized and refined members of humanity and who was excluded, who was not even human at all.

The second argument $I$ have made is that the meaning of music can change dramatically depending on the types of situations, practices, and performances which characterize the listener's encounter with the music. Focusing on the emotional impact of music, I have emphasized the importance of the encounter

\footnotetext{
${ }^{107}$ Gilbert, Music, 187.

${ }^{108}$ For more on the concept, see Alfred McCoy, A Question of Torture: CIA Interrogation, from the Cold War to the War on Terror (New York: Metropolitan Books, 2006). McCoy traces the origin of "no-touch torture" to a research program funded by the OSS, the CIA, and the intelligence services of Canada and Britain in the years after World War II.

${ }^{109}$ McCoy, Question of Torture, 57.

${ }^{110}$ Quoted in Cusick, "Music as Torture.”
} 
between a person's inner world and the external world in assigning meaning to music. I call this encounter a contact zone, which can be interpreted as an imagined space in the subject herself where engagement, communication, discord, and negotiation all may occur. The perception of music is strongly linked with experiences and emotions that have already been internalized by the listener, and thus hearing music connects one's past with the present. Music therefore serves in a positive way as an excellent medium for identity-building, formulating a self-conception, and preserving a sense of self-assurance. The opposite, however, can also be achieved, with music working to deconstruct identities.

The intentions were the same as those behind shaving prisoners' heads, assigning them numbers, forcing them to wear the same uniform, and subjecting them to brutal and arbitrary violence: SS guards used music to humiliate the prisoners, to torment them, to rob them of their individuality. Nevertheless, music differed from these more obvious forms of violence and dehumanization in one important respect. By shearing off prisoners' hair or tattooing numbers onto their arms, the SS clearly and visibly marked their absolute power over the prisoners' bodies directly onto those bodies themselves. Some prisoners describe how important it was to them that these rituals, as degrading as they were, could not exert control over their sense of self. Their knowledge, their abilities and skills, and their memories could not be taken from them as they passed through the camp's gate. Instead, these remained a resource for survival, working as "an omnipresent (survival)-motor," as Maja Suderland puts it. ${ }^{111}$ This resource and the sense of certainty that accompanied it were lost when prisoners were coerced to play or listen to music in the contexts described above. The types of catastrophic effects this could have can be clearly inferred from one study's identification of the most important factors in camp detainees' survival, the results of which were published in the Auschwitz-Hefte: "One cannot overestimate the important role positive emotional attitude and outlook played in prisoners' struggles to preserve a sense of their humanity and ensure their own survival." ${ }^{112}$ This positive emotional attitude and outlook is exactly what was under attack in situations in which music was used as a form of torture or to accompany torture. Prisoners' identities themselves were assaulted by this refashioning of music from a source of pleasure to a means of torture. The routinized, repetitive, and normalized use of music in situations characterized by despair, helplessness, and degradation hollowed out the "self's territories," destroying the person's self-assurance and robbing the prisoner of an essential force vital to survival. ${ }^{113}$

This examination has shown that in the context of absolute power and violence, music does not necessarily have a civilized or civilizing impact. The clash between internalized expectations and emotions related to music and the actual perception of music in new circumstances that are completely antithetical to earlier experiences results in the appearance of new emotions such as despair, helplessness, and fear, all of which make their mark on the mindful body. In the camps, the feeling of hopelessness manifested itself externally in their bodies. Their broken souls left them without the will to physically survive. It is important to understand the concrete ways music can be and is used to mistreat prisoners. To that end, I suggest that we must take music as torture more carefully into account and focus on the concrete link between music, emotion, the body, and questions of the construction—and deconstruction—of identities.

\footnotetext{
${ }^{111}$ See Maja Suderland, "Bildung, Distinktion und Habitus: Überlebensressourcen in der sozialen Welt der nationalsozialistischen Konzentrationslager,” Zeitschrift für Soziologie der Erziehung und Sozialisation, 23 (2003): $302,317$.

${ }^{112}$ Zenon Jagoda, Stanisław Kłodziński, and Jan Malowski, "Das Überleben im Lager aus der Sicht ehemaliger Häftlinge von Auschwitz-Birkenau," in Die Auschwitz-Hefte: Texte der polnischen Zeitschrift Przegląd lekarski über historische, psychische und medizinische Aspekte des Lebens und Sterbens in Auschwitz, ed. Hamburger Institut für Sozialforschung, vol. 1 (Weinheim: Beltz, 1987), 21 .

${ }^{113}$ Suderland, Territorien des Selbst.
} 


\section{Works Cited}

\section{Printed Sources}

Ahmed, Sara. "Collective Feelings: Or, the Impression Left by Others." Theory, Culture E Society 21 (2004): 25-42. http://dx.doi.org/10.1177/0263276404042133.

Bejarano, Esther. "Das Singen ist mir in Auschwitz vergangen.” Kontrapunkt 2 (1989): 18-19.

"Man nannte mich Krümel”: Eine jüdische Jugend in den Zeiten der Verfolgung. Hamburg: Curio, 1989.

Bohlman, Philip V. "Germany \ II, 4, Modern and Postmodern Context." In The New Grove: Dictionary of Music and Musicians, 2nd ed., vol. 9, edited by Stanley Sadie, 740-743. London: Macmillan, 2001.

Brauer, Juliane. Musik im Konzentrationslager Sachsenhausen. Berlin: Metropol, 2009.

. "Aleksander Kulisiewicz." In Lexikon verfolgter Musikerinnen und Musiker der NS-Zeit (2010).

Accessed September 25, 2013. http://www.lexm.uni-

hamburg.de/object/lexm_lexmperson_00002619.

. "Peter Bach." In Lebensspuren: Biografische Skizzen von Opfern der NS-Tötungsanstalt Hartheim, edited by Florian Schwanninger and Irene Zauner-Leitner, 87-90. Innsbruck: Studienverlag 2013.

.."Singing for Life and Death. Jewish Prisoners at Sachsenhausen Concentration Camp." In Voices of Displacement: Music and Memory in the German Jewish Experience in Modernity, edited by Yael SelaTeichler and Philip V. Bohlman (forthcoming in 2016).

Cochrane, Tom, Bernardino Fantini, and Klaus R. Scherer. The Emotional Power of Music: Multidisciplinary Perspectives on Musical Arousal, Expression, and Social Control. Oxford: Oxford University Press, 2013. http://dx.doi.org/10.1093/acprof:oso/9780199654888.001.0001.

Cusick, Suzanne G. "Music as Torture/Music as Weapon.” TRANS-Transcultural Music Review 10, no.11 (2006). http://www.sibetrans.com/trans/a152/music-as-torture-music-as-weapon.

. " "You are in a place out of the world': Music in the Detention Camps of the Global War in Terror." Journal of the Society for American Music 2 (2008): 1-26. http://dx.doi.org/10.1017/S1752196308080012.

—_. "Musicology, Torture, Repair." Radical Musicology 3 (2008): n. p.

Cusick, Suzanne G., and Branden W. Joseph. "Across an Invisible Line: A Conversation about Music and Torture.” Grey Room: Architecture, Art, Media, Politics 42 (2011): 6-22.

Dahm, Annkatrin. "Musik in den nationalsozialistischen Vernichtungszentren Belzec, Sobibor und Treblinka." Musica reanimata 23 (1997): 1-11.

—. Der Topos der Juden: Studien zur Geschichte des Antisemitismus im deutschsprachigen Musikschriftum. Göttingen: Vandenhoeck \& Ruprecht, 2007.

DeNora, Tia. After Adorno: Rethinking Music Sociology. Cambridge: Cambridge University Press, 2003. http://dx.doi.org/10.1017/CBO9780511489426.

—. Music in Everyday Life. Cambridge: Cambridge University Press, 2000. http://dx.doi.org/10.1017/CBO9780511489433.

Diner, Diner. "Rupture in Civilization': On the Genesis and Meaning of a Concept in Understanding." In On Germans and Jews under the Nazi Regime: Essays by Three Generations of Historians; a Festschrift in Honor of Otto Dov Kulka, edited by Moshe Zimmermann, 33-49. Jerusalem: Hebrew University Magnes Press, 2006. 
Dunin-Wassowicz, Krzysztof. Resistance in the Nazi Concentration Camps 1933-1945 Translated by Halina Dzierżanowska. Warszawa: PWN, 1982. Originally published as Ruch oporu $w$ hitlerowskich obozach koncentracyjnych, 1933-1945 (Warzawa: PWN, 1979).

Fackler, Guido. "Wir spüren alle, daß diese Musik infernalisch ist': Musik in Auschwitz." In The Last Expression: Art and Auschwitz. Exhibition prepared by Mary and Leigh Block Museum of Art, Northwestern University. http://lastexpression.northwestern.edu/arts_fr_e_fack.html.

. "Des Lagers Stimme" - Musik im KZ: Alltags und Häftlingskultur in den Konzentrationslagern 1933 bis 1936. Bremen: Ed. Temmen, 2000.

Fenelon, Fania, and Marcelle Routier. Playing for Time. New York: Atheneum, 1977. Originally published as Sursis pour l'orchestre (Paris: Stock, 1976.)

—. Das Mädchenorchester in Auschwitz. Frankfurt am Main: Röderberg, 1980.

. "Nach Mord Schumanns Träumerei." Interview by Niklas Frank. Stern 33 (1980): 41.

Flam, Gila. Singing for Survival: Songs of the Lodz Ghetto. Urbana: University of Illinois Press, 1992.

Fritz, Mali. Essig gegen den Durst: 565 Tage in Auschwitz-Birkenau. Wien: Verlag für Gesellschaftskritik, 1986.

Gilbert, Shirli. Music in the Holocaust: Confronting Life in the Nazi Ghettos and Camps. Oxford: Clarendon Press, 2005.

Giner, Bruno. Survivre et mourir en musique dans les camps Nazis. Paris: Berg International, 2011.

Goodman, Steve. Sonic Warfare: Sound, Affect, and the Ecology of Fear. Cambridge, MA: MIT Press, 2010.

Gutman, Yiśra'el, and Michael Berenbaum, eds. Anatomy of the Auschwitz Death Camp. Washington: Indiana University Press, 1994.

Grant, Morag J., and Anna Papaeti, eds. Music and Torture / Music and Punishment. Special issue of The World of Music (new series) 2 (2013): 1.

_. "Introduction." Torture: Journal of Rehabilitation of Torture Victims and Prevention of Torture 23 (2013): $1-3$.

Grant, Morag J. “The Illogical Logic of Music Torture.” Torture: Journal of Rehabilitation of Torture Victims and Prevention of Torture 23 (2013): 4-13.

—_. "Pathways to Music Torture." Transposition 4 (2014). http://transposition.revues.org/494

HaCohen, Ruth. Music Libel against the Jews. New Haven: Yale University Press, 2011.

Hesmondhalgh, David. "Towards a Critical Understanding of Music, Emotion and Self-Identity." Consumption Markets \& Culture 11 (2008): 329-343. http://dx.doi.org/10.1080/10253860802391334.

Hirsch, David D. "Camp Music and Camp Songs: Szymon Laks and Aleksander Kulisiewicz." In Confronting the Holocaust: A Mandate for the 21st Century, Studies in the Shoah, edited by G. Jan Colijn and Marcia Sachs Littell, 157-168. Oxford: University Press of America.

Hirsch, Lily E. "'Do you really want to hurt me?' Music as Punishment in the United States Legal System." Popular Music and Society 34, no. 1 (2011): 35-53. http://dx.doi.org/10.1080/03007766.2011.539818.

—. Music in American Crime Prevention and Punishment. Ann Arbor: University of Michigan Press, 2012.

Jagoda, Zenon, Stanisław Kłodziński, and Jan Malowski. "Das Überleben im Lager aus der Sicht ehemaliger Häftlinge von Auschwitz-Birkenau.” In Die Auschwitz-Hefte: Texte der polnischen Zeitschrift Przeglad lekarski über historische, psychische und medizinische Aspekte des Lebens und Sterbens in Auschwitz, vol. 1, edited by Hamburger Institut für Sozialforschung, 13-25. Weinheim: Beltz, 1987. Published 
in Polish as Przegląd lekarski: organ Towarzystwa Lekarskiego Krakowskiego (Oddzia lu PTL, Kraków).

John, Eckhard. "Music and Concentration Camps: An Approximation." Journal of Musicological Research 20, no. 4 (2001): 269-323. Originally published as "Musik und Konzentrationslager: Eine Annäherung," Archiv für Musikwissenschaft 48 (1991): 1-36. http://dx.doi.org/10.2307/930869.

Johnson, Bruce, and Martin Cloonan, eds. Dark Side of the Tune: Popular Music and Violence. Burlington: Ashgate, 2008.

Juslin, Patrik N., and John A. Sloboda. Handbook of Music and Emotion: Theory, Research, Applications. Oxford: Oxford University Press, 2010.

Kalisch, Shoshana, and Barbara Meister. Yes We Sang! Songs of the Ghettos and Concentration Camps. New York: Harper \& Row, 1985.

Kaczerginski, Shmerke. Lider Fun di Getos un Lagern. New York: Tziko Bicher Farlag, 1948.

Karas, Joža. Music in Terezín 1941-1945. New York: Beaufort, 1985.

Kaufman Shelemay, Kay. "Musical Communities: Rethinking the Collective in Music." Journal of the American Musicological Society 64, no. 2 (2011): 349-390. http://dx.doi.org/10.1525/jams.2011.64.2.349.

Kłodziński, Stanisław and Jan Malowski. "Vernichtung durch Arbeit: Zur Pathologie der Arbeit im Konzentrationslager.” In Die Auschwitz-Hefte: Texte der polnischen Zeitschrift Przeglad lekarki über historische, psychische und medizinische Aspekte des Lebens und Sterbens in Auschwitz, vol. 2, edited by Hamburger Institut für Sozialforschung, 135-147. Weinheim: Beltz, 1987. Published in Polish as Przegląd lekarski: organ Towarzystwa Lekarskiego Krakowskiego (Oddzia lu PTL, Kraków.)

Knapp, Gabriele. "Das Frauenorchester vom Auschwitz-Birkenau: Bewältigungsformen musikalischer Zwangsarbeit." Musik von unten. Verein für demokratische Musikkulturen in Geschichte und Gegenwart Informationsblatt 8/9 (1995/1996): 15-32.

—. Das Frauenorchester in Auschwitz: Musikalische Zwangsarbeit und ihre Bewältigung. Hamburg: von Bockel, 1996.

__ Frauenstimmen: Musikerinnen erinnern an Ravensbrück. Berlin: Metropol, 2003.

Kon, Henech. 30 Songs of the Ghetto. New York: Congress for Jewish Culture, 1960.

Kreuzheck, Hans-Ludger. "Kapellen der Hölle: Die offiziellen Lagerkapellen in Auschwitz und anderen Konzentrationslagern, Part 1." Musik von unten. Verein für demokratische Musikkulturen in Geschichte und Gegenwart Informationsblatt 17 (1995): 33-44.

. "Kapellen der Hölle: Die offiziellen Lagerkapellen in Auschwitz und anderen

Konzentrationslagern, Part 2." Musik von unten. Verein für demokratische Musikkulturen in Geschichte und Gegenwart Informationsblatt 18 (1995): 28-43.

. "Kapellen der Hölle: Die offiziellen Lagerkapellen in Auschwitz und anderen

Konzentrationslagern, Part 3." Musik von unten. Verein für demokratische Musikkulturen in Geschichte und Gegenwart Informationsblatt 19 (1995): 3-23

- "Musik im KZ: Allgemeine Überlegungen aus Anlaß einer Buchbesprechung." DIZ Nachrichten 18 (1996): 44-50.

Kulisiewicz, Aleksander. "Z zagadnień psychopatologii muzyki i pieśni w obozach hitlerowskich” (Psychopathology of Music and Songs in Nazi Concentration Camps). Przeglad Lekarski 31, no. 1 (1974): 39-45. 
. "Dalsze przyczynki do zagadnień psychopatologii muzyki i pieśni w obozach hitlerowskich" (Additional Contributions towards a Psychopathology of Music and Songs in Nazi Concentration Camps). Przegląd Lekarski 32, no. 1 (1975): 33-40.

- "Muzyka i pieśni jako współczynnik samoobrony psychicznej więzńiów w obozach hitlerowskich" (Music and Songs as a Factor in Prisoners' Psychological Self-Defense in Nazi Camps). Przeglad Lekarski 34, no. 1 (1977): 66-77.

-. "Dalsze przyczynki do zagadnień muzyki i pieśni w zakresie samoobrony psychicznej więzńiów w obozach hitlerowskich" (Further Considerations on Music and Songs in Prisoners' Psychological Self-Defense in Nazi Camps). Przeglad Lekarski 36, no. 1 (1979): 38-50.

—. Sachsenhausen Pamiętnik poetycki 1939-1945. Lublin: 1965. Published in German as Adresse Sachsenhausen. Literarische Momentaufnahmen aus dem KZ, ed. Claudia Westermann (Gerlingen: Bleicher Verlag 1997).

Kuna, Milan. Hudba na hranici života: O činnosti a utrpení hudebníků z českých zemí vnacistických koncentračních táborech a věznicích. Prague: Naše vojsko, 1990.

Lammel, Inge, and Günter Hofmeyer. Lieder aus den faschistischen Konzentrationslagern (Das Lied - im Kampf geboren, Heft 7). Leipzig: Hofmeister, 1962.

Lammel, Inge. "Zur ethischen Funktion des deutschen KZ-Liedes." Musik und Gesellschaft 16 (1966): 148153.

_- Lied und Gesang im illegalen Widerstand gegen den Faschismus in Deutschland 1933-1945. Berlin: Akademie der Künste der DDR, 1977.

Laks, Szymon. Music of Another World. Evanston: Northwestern University Press, 1989. Originally published in French in 1948.

Lasker-Wallfisch, Anita. Inherit the Truth, 1939-1945: The Documented Experiences of a Survivor of Auschwitz and Belsen. New York: St. Martin's Press, 2000.

Levi, Primo. If This Is a Man/The Truce. Suffolk: Abacus, 1987.

Martini, Joachim. Musik in Auschwitz: Begleitheft zur gleichnamigen Ausstellung, Evangelische Initiative: Zeichen der Hoffnung, Znaki Nadziei. Frankfurt am Main, 1988.

McCoy, Alfred. A Question of Torture: CIA Interrogation, from the Cold War to the War on Terror. New York: Metropolitan Books, 2006.

Miehling, Klaus. Gewaltmusik - Musikgewalt: Populäre Musik und die Folgen. Würzburg: Königshausen \& Neumann, 2006.

Milewski, Barbara. "Remembering the Concentration Camps: Aleksander Kulisiewicz and His Concerts of Prisoner's Songs in the Federal Republic of Germany." In Dislocated Memories: Jews, Music, and Postwar German Culture, edited by Tina Frühauf and Lily E. Hirsch, 141-160. Oxford; New York: Oxford University Press, 2014. http://dx.doi.org/10.1093/acprof:oso/9780199367481.003.0007.

Moreno, Joseph J. "Orpheus in Hell: Music in the Holocaust." In Music and Manipulation: On the Social Uses and Social Control of Music, edited by Steven Brown and Ulrik Volgsten, 264-286. New York: Berghahn Books, 2006.

Morsch, Günther. Mord und Massenmord im Konzentrationslager Sachsenhausen: 1936- 1945. Berlin: Metropol, 2005.

Morsch, Günter, and Astrid Ley. Sachsenhausen Concentration Camp 1936-1945: Events and Developments. Berlin: Metropol, 2008. 
Naliwajek-Mazurek, Katarzyna. "Music and its Emotional Aspects during the Nazi Occupation of Poland." In Besatzungsmacht Musik: Zur Musik- und Emotionsgeschichte im Zeitalter der Weltkriege (19141949). Edited by Sven Oliver Müller and Sarah Zalfen, 207-226. Bielefeld: Transcript, 2012. http://dx.doi.org/10.14361/transcript.9783839419120.207.

- "Music and Torture in Nazi Sites of Persecution and Genocide in Occupied Poland 1939-1945." In The World of Music (new series) 2 (2013): 31-50.

Newman, Richard, and Karen Kirtly. Alma Rosé: Vienna to Auschwitz. Portland, OR: Amadeus Press, 2000.

Petersen, Peter, ed. Zündende Lieder - Verbrannte Musik: Folgen des Nazifaschismus für Hamburger Musikerinnen und Musiker. Hamburg: VsA, 1995.

Pieslak, Jonathan. Sound Targets: American Soldiers and Music in the Iraq War. Bloomington: Indiana University Press, 2009.

Pratt, Mary Louise. Imperial Eyes: Travel Writing and Transculturation. London: Routledge, 1992. http://dx.doi.org/10.4324/9780203163672.

Rees, Laurence. Auschwitz: A New History. New York: Public Affairs, 2005.

Reichmann, Hans. Deutscher Bürger und verfolgter Jude: Novemberpogrom und KZ Sachsenhausen 1937-1939. Edited by Michael Wildt. Munich: Oldenburg, 1998.

Sachnowitz, Hermann. Auschwitz: Ein norwegischer Jude überlebte. Frankfurt am Main: Büchergilde Gutenberg, 1981.

Scheer, Monique. "Are Emotions a Kind of Practice (and Is That What Makes Them Have a History)? A Bourdieuian Approach to Understanding Emotion." History and Theory 51 (2012): 193-220. http://dx.doi.org/10.1111/j.1468-2303.2012.00621.x.

Scheper-Hughes, Nancy, and Margaret M. Lock. "The Mindful Body: A Prolegomenon to Future Work in Medical Anthropology." Medical Anthropology Quarterly 1 (1987): 6-41. http://dx.doi.org/10.1525/maq.1987.1.1.02a00020.

Schumann, Coco. Der Ghetto-Swinger. Munich: Deutscher Taschenbuch Verlag, 1997.

Shuldman, Ken. Jazz Survivor: The Story of Louis Bannet, Horn Player of Auschwitz. London: Vallentine Mitchell, 2005.

Springmann, Veronika. “Das ist die Moorolympiade: 'Lagersport' als Differenzproduktion in Konzentrationslagern." In Personal und Insassen von Totalen Institutionen - zwischen Konfrontation und Verflechtung, edited by Falk Bretschneider, Martin Scheutz, and Alfred Stefan Weiß, 381-394. Leipzig: Leipziger Universitätsverlag, 2011. (Part of the series Geschlossene Häuser: Historische Studien zu Orten und Institutionen der Separierung, Verwahrung und Bestrafung, vol. 3.)

Sofsky, Wolfgang. The Order of Terror: The Concentration Camp. Princeton: Princeton University Press, 1997.

—_. Traktat über die Gewalt. Frankfurt am Main: S. Fischer, 1996.

__. "An der Grenze des Sozialen - Perspektiven der KZ-Forschung." In Die nationalsozialistischen Konzentrationslager, vol. 2, edited by Ulrich Herbert, Karin Orth, and Christoph Dieckmann, 11411169. Göttingen: Wallstein, 1998.

Spiegelman, Art. Maus - A Survivor's Tale I: My Father Bleeds History. New York: Pantheon Books, 1986.

Stroumsa, Jacques. Violinist in Auschwitz: From Salonica to Jerusalem, 1913-1967. Konstanz: Hartung-Gorre, 1996. 
Strzelecka, Irena. "Women." In Anatomy of the Auschwitz Death Camp, edited by Yiśra'el Gutman and Michael Berenbaum, 393-411. Bloomington: Indiana University Press, 1994.

Strzelewicz, Konrad. Zapis: Opowieść Aleksandra Kulisiewicza (Record: The Story of Aleksander Kulisiewicz). Krakow: Krajowa Agencja Wydawnicza, 1984.

Suderland, Maja. Territorien des Selbst: Kulturelle Identität als Ressource für das tägliche Überleben im Konzentrationslager. Frankfurt am Main/New York: Campus, 2004.

- "Bildung, Distinktion und Habitus: Überlebensressourcen in der sozialen Welt der nationalsozialistischen Konzentrationslager." Zeitschrift für Soziologie der Erziehung und Sozialisation 23 (2003): 302-322.

Steinacher, Sybille. Auschwitz: A History. New York: Ecco, 2005.

Szmaglewska, Seweryna. Smoke over Birkenau. New York: Holt, 1947. (Originally published in Polish as Dymy nad Birkenau (Warszawa: Czytelnik, 1945).

Urbancyzk, M. Twórcyość i dziatność pieśniarska Aleksandra Kulisiewicza w obozie koncentracyjnym Sachsenhausen (1940-1945) (The Musical Works and Song Activities of Aleksander Kulisiewicz in Sachsenhausen [1940-1945]). Uniwersytet Śląski, 1981.

Walda, Dick. Trompettist in Auschwitz: Herinneringen van Lex van Weren. Amsterdam: De Bataafsche Leeuw, 1989.

Weiner, Lazar. Songs of the Concentration Camps. New York: Itzchok-Hendele Foundation, 1948.

Weiß-Rüthel, Arnold. Nacht und Nebel: Aufzeichnungen aus fünf Jahren Schutzhaft. Munich: Kluger, 1946.

Werb, Bret, and Milewski, Barabara. "From Madagascar to Sachsenhausen: Singing about 'Race' in a Nazi Camp.” In Polin: Studies in Polish Jewry, 16 (2003), 269-278.

\section{Unpublished Sources}

Červinka, Bohumir. Die Musik, die Trösterin der Traurigen und die Aufmunterung der Tapferen. Oranienburg: Archive of Sachsenhausen Museum: (AS) P3 Červinka, Bohumir, without year.

Haase, Hans. Zeugenmeldung an die Staatsanwaltschaft Bonn. Oranienburg: Archive of Sachsenhausen Museum, February 1956: JD 2/3.

König, Adam. Interview with Juliane Brauer. Berlin. April 30, 2004.

Kulisiewicz, Aleksander. Liedermacher im Kampf gegen Faschismus - Kunst im Konzentrationslager - Lieder als Zeugen der Geschichte. Krakau 1975, Berlin Arbeiterlied Archiv der Akademie der Künste, Sign. 2.

Kulisiewicz, Aleksander. Muzyka i pieśni w hitlerowskich obozach konzcentracyjnych 1933-1945 (Music and Songs in the Fascist Concentration Camps). Krakow, Poland, without date, Oranienburg: Archive of Sachsenhausen Museum: P3.

Quade, Berthold. Konzentrationslager Sachsenhausen. Bericht über die Vorkriegszeit 1936-1939, Potsdam: Archive for federal state Brandenburg, without year, rep. 35 H, Nr. 29.

Rheder, Willy. Zeugenaussage, Landeskriminalpolizeidienststelle Stada, 16.06.1961, Archive of Sachsenhausen Museum: (AS) JD 7/8, 55.

Scheidel, Erwin. Zeugenvernehmung im Ermittlungsverfahren gegen Sorge, Gustav und Schubert, Wilhelm (Oberscharfïhrer) wegen Mordes, Interrogation record dated March 28, 1956. Oranienburg: Archive of Sachsenhausen Museum, Sig. JD 2/12. 
Szepansky, Wolfgang. Beitrag zur Dokumentation der Geschichte des KZ Sachsenhausen. Manuskript über seine Häftlingszeit im KZ Sachsenhausen. Berlin, without date. Arbeiterlied Archiv der Akademie der Künste, sign. 10.

\section{Visual/Audio Sources}

Aleksander Kulisiewicz, Ballads and Broadsides: Songs from Sachsenhausen, United States Holocaust Museum 2008.

"Camp orchestra". Picture taken by the SS. 1941. Accessed January 11, 2013. http://en.auschwitz.org/m/index.php?option $=$ com_ponygallery\&func $=$ detail\&id $=1149 \& I t e m i d=3$.

"Prisoners' orchestra during a Sunday concert for the SS-men in Auschwitz. The orchestra was probably conducted by the inmate Franciszek Nierychlo. [Photograph \#81216].” 1941. Accessed January 11, 2013.

http://digitalassets.ushmm.org/photoarchives/detail.aspx?id=12074\&search=\%2381216\&index=1.

Eleanor Mlotek, We are Here: Songs of the Holocaust. New York: Educational Dep. of the Workmen's Circle, 1983.

Holocaust. Directed by Marvin J. Chomsky. 1978. Hollywood: Paramount Home Entertainment, 2008. DVD.

Lotoro, Francesco, Tiritiello, Grazia. KZ Musik: Encyclopedia of Music Composed in Concentration Camps 1933-1945. 24 volumes. Rome: Assoc. Culturale, 2008/9, compact disk.

Ostatni Etap (The Last Stage). Directed by Wanda Jakubowska. Poland, 1947; Chicago: Facets Video, 2009. DVD.

Pasazerka (Passenger). Directed by Andrzej Munk. Poland, 1963; Bellingham: Hen’s Tooth Video, 1997. VHS.

\section{Websites}

Free Floater Research Group: Music, Conflict and the State. Head of Research Group: Morag Josephine Grant. Accessed January 8, 2013. http://www.uni-goettingen.de/de/84354.html.

Lexikon verfolgter Musikerinnen und Musiker der NS-Zeit. Accessed September 26, 2013. http://www.lexm.uni-hamburg.de/content/below/index.xml.

United States Holocaust Memorial Museum. "Music of the Holocaust: Highlights from the Collection." Accessed January 18, 2013. http://www.ushmm.org/museum/exhibit/online/music.

USC Shoah Foundation, The Institute for Visual History and Education. "Visual History Archive." Accessed January 10, 2013. http://sfi.usc.edu.

World ORT. "Music and the Holocaust." Accessed January 18, 2013. http://holocaustmusic.ort.org/. 


\begin{abstract}
Singing on command, playing instruments in prisoners' orchestras and having to listen to this music was part of daily life in German Nazi Camps. SS-guards in many concentration and extermination camps purposefully used music to attack prisoners' identities, certainties and self-conceptions. Music in National Socialist camps was therefore a special kind of violence and torture. Focusing on the impact of music on the body through the lens of the emotion, this article argues that music, in its performativity and its performative effect, has the ability to affect the human body and, therefore, the emotions. Its strong, positive power to help people to survive stems from this ability. But it is also this strong impact which may become a destructive power. This article aims to illuminate how and why music can exert this power and how it was used by SS camp guards and perceived by prisoners as a special kind of violence and torture. It focuses on different situations of singing on command in concentration camp Sachsenhausen and on playing music in prisoners' orchestras, as well as listening to music in extermination camp Auschwitz Birkenau. By surveying the various ways in which music was embedded in violence in the camps and by interrogating the interplay between music, emotions and the body, this article seeks to offer an explanation of the potentially torturous nature of music and to clarify why it was used specifically in these sites and contexts.
\end{abstract}

